\title{
Saccharomyces boulardii CNCM I-745 supports regeneration of the intestinal microbiota after diarrheic dysbiosis - a review
}

REVIEW

\author{
Margret I Morél \\ Alexander Swidsinski ${ }^{2}$ \\ 'analyze \& realize $\mathrm{GmbH}$, Berlin, \\ Germany; ${ }^{2}$ Laboratory for Molecular \\ Genetics, Polymicrobial Infections \\ and Bacterial Biofilms, Department of \\ Medicine, Gastroenterology, Charité \\ Hospital, CCM, Universitätsmedizin \\ Berlin, Berlin, Germany
}

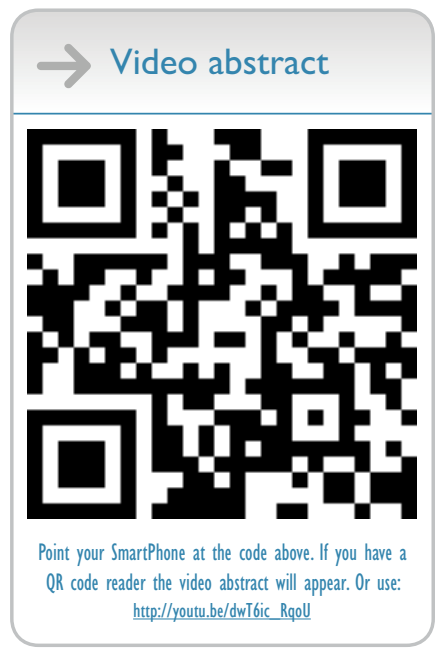

Correspondence: Margret I Moré analyze \& realize $\mathrm{GmbH}$,

Waldseeweg 6, 13467 Berlin, Germany

Tel +49304000 8I57

Fax +493040008457

Email mmore@analyze-realize.com
This article was published in the following Dove Press journal:

Clinical and Experimental Gastroenterology

14 August 2015

Number of times this article has been viewed

\begin{abstract}
The probiotic medicinal yeast Saccharomyces cerevisiae HANSEN CBS 5926 (Saccharomyces boulardii CNCM I-745) is used for the prevention and treatment of diarrhea. Its action is based on multiple mechanisms, including immunological effects, pathogen-binding and antitoxinic effects, as well as effects on digestive enzymes. Correlated with these effects, but also due to its inherent properties, $S$. boulardii is able to create a favorable growth environment for the beneficial intestinal microbiota, while constituting extra protection to the host mucus layer and mucosa. This review focuses on the positive influence of $S$. boulardii on the composition of the intestinal microbiota. In a dysbiosis, as during diarrhea, the main microbial population (especially Lachnospiraceae, Ruminococcaceae, Bacteroidaceae, and Prevotellaceae) is known to collapse by at least one order of magnitude. This gap generally leads to transient increases in pioneer-type bacteria (Enterobacteriaceae, Bifidobacteriaceae, and Clostridiaceae). Several human studies as well as animal models demonstrate that treatment with $S$. boulardii in dysbiosis leads to the faster reestablishment of a healthy microbiome. The most relevant effects of $S$. boulardii on the fecal composition include an increase of short chain fatty acidproducing bacteria (along with a rise in short chain fatty acids), especially of Lachnospiraceae and Ruminococcaceae, as well as an increase in Bacteroidaceae and Prevotellaceae. At the same time, there is a suppression of pioneer bacteria. The previously observed preventive action of $S$. boulardii, eg, during antibiotic therapy or regarding traveler's diarrhea, can be explained by several mechanisms, including a stabilizing effect on the healthy microbiota as well as possibly on the mucus layer. Several different dysbiotic situations could profit from the effects of $S$. boulardii CNCM I-745. Its additional potential lies in a general stabilization of the gut flora for at-risk populations. More studies are needed to explore the full potential of this versatile probiotic yeast.
\end{abstract}

Keywords: Saccharomyces boulardii CNCM I-745, microbiota, diarrhea, dysbiosis, colonic bioreactor, intestinal mucus layer, mucosa, SCFA, probiotic

\section{Search method}

The research was done in the databases Medline (http://www.ncbi.nlm.nih.gov/ pubmed) and PubMed Central (PMC; http://www.ncbi.nlm.nih.gov/pmc/), searching for Saccharomyces boulardii (480 entries in Medline and 705 entries in PMC as of January 2015). All publications detailing effects of $S$. boulardii on the microbiota were evaluated. Further literature was found after searching for terms relevant to the specific topic (eg, combinations of colon, study, SCFA [short chain fatty acid], butyrate, immune system, microbiota, dysbiosis, antibiotic, probiotic, prebiotic, etc) and following up literature citations. 


\section{Introduction Objective of this review}

This review focuses on the positive influence of $S$. boulardii on the composition of the intestinal microbiota. To understand the effects of the probiotic yeast, we first provide an up-todate review on the function of the colon and its microbiota in the healthy situation as well as during dysbiosis.

We then describe the properties of $S$. boulardii, recapitulate its clinical success, and sum up its mechanisms of action, both in the healthy situation and during dysbiosis. These mechanisms of action result in its effects on the microbiota, which have been observed in various nonclinical and clinical studies. We summarize all nonclinical and clinical studies evaluating the effects of $S$. boulardii on the microbiota, which have been published to date. Derived from the study results, we conclude specific effects of $S$. boulardii on various microbial groups during dysbiosis, leading to an overall improved regeneration of the microbiota. In the final discussion, a broader use potential of $S$. boulardii is suggested.

\section{The healthy colon and its microbiota}

In the healthy intestine, a thick mucus layer separates the intestinal wall from the densely populated intestinal contents, with $10^{12}$ bacteria/g of stool within the colon. ${ }^{1}$ The contained bacteria include many potentially harmful species, which thrive on the nutrient supply from the already partially predigested food in a mostly fermentative lifestyle.

The colonic "bioreactor" has several important functions:

- The microbial production of SCFA (eg, butyrate), a prominent nutrient for the human host fulfilling various regulatory functions ${ }^{2-6}$

- The microbial production of valuable secondary metabolites and vitamins, which are taken up by the human host - colectomy leads to malnutrition ${ }^{7}$

- Nutrient/drug processing and salvage $e^{8,9}$

- General immune system awareness ${ }^{10-12}$

- Influence on energy homeostasis, glucose metabolism, and lipid metabolism ${ }^{13}$

- Water and electrolyte recycling from the intestinal contents.

The bioreactor is kept running by a microorganisminduced program of epithelial cell homeostasis and repair. ${ }^{14}$ In addition, the colonic mucus disables bacterial movements and excludes the microbiota from direct epithelial contact. ${ }^{15}$

The mucus consists of mucin glycoproteins, produced by goblet cells. ${ }^{15}$ It is condensed by continuous water resorption.
The inner mucin layer is densely packed, and the small pore size physically prevents bacterial penetration. ${ }^{16}$

The outer part of the mucus layer is more porous and is infiltrated with bacteria. ${ }^{17}$ It may form laminar mucus structures. This so-called germinal stock area functions as a reservoir of the microbiota, even if most of them are regularly discharged. ${ }^{18}$ The feces itself is also covered by mucus, derived from the outer mucus layer.

\section{The colonic microbiota during intestinal dysbiosis}

Intestinal dysbiosis can be defined as an unfavorable dysbalance of the intestinal microbiota. In addition, microscopic examination has shown a disruption of the protective mucus layer for different diarrheic dysbiotic situations, including inflammatory bowel disease (IBD; either Crohn's disease or ulcerative colitis), irritable bowel syndrome (IBS), acute diarrhea, human immunodeficiency virus (HIV) enteropathy, and other intestinal conditions, resulting in bacteria directly attaching to the exposed mucosa and eliciting a polymicrobial infection. . $^{15,19,20}$

Several conditions may lead to a dysbiosis; in addition, there are certain risk factors, eg, malnutrition, old age, diabetes/metabolic syndrome, ${ }^{21,22}$ and stress, that additionally destabilize the microbiota (Figure 1).

The disruption of the normal intestinal microflora by antibiotics is a common cause of dysbiosis in the industrialized world. Individuals who never received antibiotics throughout their lifetime are a minority, a fact that raises concerns since this practice may lead to a long-term deprivation and alteration of the microbiota within the entire population. ${ }^{23-25}$

Both parenteral and enteral nutrition were found to lead to a bacterial unbalance, ${ }^{26,27}$ specifically, butyrate producers and starch degraders were found to be drastically reduced in the feces of critically ill tube-fed patients, with promising antidiarrheic results after fiber supplementation. ${ }^{28,29}$

Irritable bowel syndrome is characterized by an increased permeability and an altered immune profile, as well as central nervous and gut neuromuscular impacts. ${ }^{30}$ This can lead to small intestinal bacterial overgrowth as well as hypersensitive bowel movements. ${ }^{31}$

The chronic inflammatory conditions, Crohn's disease and ulcerative colitis, go along with a reduced microbial diversity and differences in the microbial community structure at the inflamed sites. ${ }^{32}$ For chronic situations as in IBD, the cause-effect relationship may rather be a vicious circle between dysbiosis and altered physiology. ${ }^{33}$ 


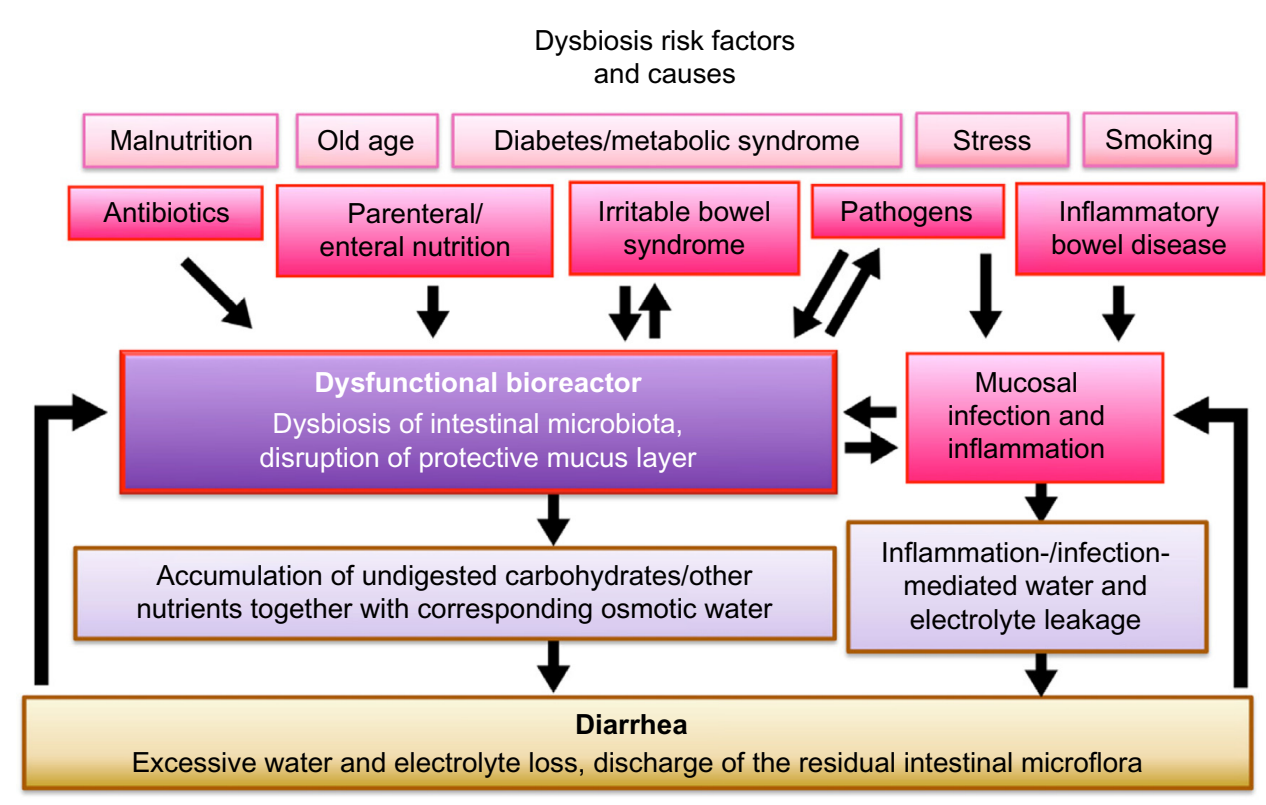

Figure I Dysbiosis of intestinal microbiota during diarrhea.

Notes: The gastrointestinal tract harbors a complex microbial ecosystem that coexists in equilibrium with the host. When this equilibrium is disrupted, dysbiosis can manifest itself in a vicious cycle, prolonging diarrheic symptoms.

Certainly, many cases of dysbiosis - including lifethreatening diarrheic conditions - are induced by pathogens (eg, rotaviruses or various bacterial pathogens) ${ }^{34-36}$ On top of this, acute gastrointestinal infections lead to an increased incidence of IBS. ${ }^{37}$ Also, an association between antibiotic use and an increased risk of persistent digestive symptoms in children has been shown. ${ }^{38}$ Vice versa, a disruption of the intestinal bacterial population along with a disruption of the mucus barrier favors bacterial pathogens (eg, Peptoclostridium [Clostridium] difficile). ${ }^{39}$

In addition, people affected by autism spectrum disorders display symptoms of gastrointestinal disturbance along with an altered microbiota. ${ }^{40,41}$ Interestingly, also extreme, lifethreatening physical situations, like stroke or severe brain injury, lead to diarrheic dysbiosis, accompanied by leukocyte infiltration of the mucus layer similar to ulcerative colitis, with similar microbial changes. ${ }^{42}$

Dysbiosis along with a mucus destabilization can result in diarrhea and accompanying conditions like bloating, flatulence, and cramping.

This can be explained as follows:

1. A disrupted microflora can only insufficiently bind and metabolize the minerals, carbohydrates, and other nutrients usually taken up as "nutrition" - they remain in the intestinal lumen together with a corresponding quantity of osmotic water: the result is more watery stools.

2. Also, the reduction of SCFA (eg, butyrate)-producing bacteria results in a reduced amount of SCFA, with consequences.
Normally, SCFA signaling in the intestine suppresses insulin-mediated fat accumulation ${ }^{43}$ and inhibits food intake by appetite control. ${ }^{3}$ Thus, long-term SCFA reduction is correlated with increase in body weight. ${ }^{22}$ This goes along with the observation that obese people suffer from chronic diarrhea more often than normal weight people. ${ }^{44}$

In addition, SCFAs have epithelial growth-promoting and anti-inflammatory effects ${ }^{45}$ as well as a variety of other health-promoting effects. ${ }^{5}$ Thus, if SCFAs are reduced, inflammation and disease can take over more easily.

3. The activation of an immune and repair response in the intestine is induced by bacterial products reaching Tolllike receptors on the inner side of the epithelial cells due to damage of the barrier function. ${ }^{14}$

A mucosal inflammatory response results in a reduced tight junction-mediated barrier function, ${ }^{46-48}$ correlated with water and electrolyte leakage. This condition also can be considered an attempted discharge of potential pathogens, together with a substantial number of the other intestinal inhabitants.

4. As a consequence, the total microbial concentration in the colon is significantly reduced during diarrhea..$^{18,49}$ This goes along with increased intestinal motility. The bioreactor is purging itself.

Inflammatory reactions like leukocyte infiltration have the role of clearing the mucosa from potential pathogens. Replacement of damaged or infected epithelial cells and 
rebuilding of an intact mucus layer are prerequisite for the return to a healthy situation.

Although dysbiosis often leads to diarrhea, there may be situations in which an unbalanced microbiota produces regular stools most of the time, while still manifesting itself in a low-level intestinal inflammation.

Especially in countries with high technology standards, an increasing amount of food containing a high burden of detergents and emulsifiers is consumed. These agents, eg, carboxymethyl cellulose, have been shown to have detrimental effects on the integrity of the intestinal mucus layer, thereby possibly furthering low-level infection - direct attachment to the mucosa - of commensal bacteria. ${ }^{50}$

In addition, there is evidence that constipation is correlated with dysbiosis. ${ }^{51,52}$

Thus, those humans in the industrialized world who are threatened by dysbiosis through risk factors like stress, old age, increased body mass/diabetes/metabolic syndrome, malnutrition, or otherwise unhealthy lifestyles together with those already suffering dysbiotic symptoms may make up a significant proportion of the entire population.

\section{Properties of S. boulardii and summary of clinical success and its mechanisms of action Probiotic properties of S. boulardii}

The natural healthy gastrointestinal microbiota only has a yeast content of $<0.1 \%$, Candida albicans being the most prominent yeast inhabitant. ${ }^{53}$

Even taking into account a "correction for the 10 times larger size," yeast represents less than $1 \%$ of the total microbiota. ${ }^{53}$

The well-known nonpathogenic medicinal yeast $S$. boulardii was originally isolated in 1923 by Henri Boulard from peels of tropical fruit. Probiotic strains of $S$. boulardii belong to Saccharomyces cerevisiae species. ${ }^{54}$ However, the $S$. boulardii strains that are used therapeutically to treat human gastrointestinal tract disorders show tight clustering, both genetically and metabolically. ${ }^{55}$

$S$. boulardii is absent from the natural gut microbiota. If administered, it achieves steady-state concentrations in the colon within 3 days and is cleared from the stools 2-5 days after discontinuation. ${ }^{56,57}$ In mice, $S$. boulardii reached $10^{7}$ colony forming units (CFU)/g of feces in a steady state, when $5 \times 10^{8} \mathrm{CFU}$ was administered daily. When the administration was stopped, the yeast still numbered $7.3 \times 10^{6} \mathrm{CFU} / \mathrm{g} 3$ days later, but was undetectable after 1 week. ${ }^{58}$
Compared with bacterial probiotics, the yeast cells of $S$. boulardii have the following advantages: they are antibiotic resistant due to their fungal nature, and they do not exchange DNA, eg, resistance genes with bacteria. ${ }^{53}$

Although the use of $S$. cerevisiae (eg, S. boulardii CNCM I-745) is considered safe, an increased number of $S$. cerevisiae infections (fungemia) have been observed in critically ill and/ or immunocompromised patients. ${ }^{59}$ Interestingly, virulence seems to be associated with an enhanced tolerance to oxidative stress ${ }^{60}$ as well as increased copy numbers of genes of the purine nucleotide synthesis pathway, which in turn increase survival rates in the bloodstream of the host. ${ }^{61}$ However, in order to cause fungemia, $S$. cerevisiae first needs to cross the intestinal barrier and reach the bloodstream in sufficient numbers.

$S$. boulardii has all necessary prerequisites as probiotic. Other than its close relative $S$. cerevisiae, it has a growth temperature optimum around $37^{\circ} \mathrm{C}$ and a relatively high acid tolerance. ${ }^{62,63}$

A substantial part of the efficacy of $S$. boulardii is dependent on its vitality, ${ }^{64,65}$ which can differ with preparation and storage techniques, lyophilized (freeze-dried) S. boulardii CNCM I-745 being clearly superior to heat-dried preparations regarding revitalization speed and growth. ${ }^{66}$

Accordingly, for the selection of therapeutic or preventive yeast products, attention should be paid not only to the used strain but also to its preparation.

\section{Clinical efficacy of S. boulardii}

Numerous clinical studies, almost all performed with lyophilized S. boulardii CNCM I-745, demonstrate efficacy and safety for a variety of gastrointestinal conditions associated with diarrhea. ${ }^{67-69}$ In contrast to other probiotics, S. boulardii was found to have a very broad clinical efficacy with significant positive effects in many different dysbiotic situations. $^{70}$

For example, there is excellent evidence from 14 of 17 total studies that $S$. boulardii can prevent antibiotic-associated diarrhea. ${ }^{71}$ Also, S. boulardii can be of advantage in preventing or reducing $C$. difficile-associated colitis ${ }^{72,73}$ or traveler's diarrhea. ${ }^{74}$ Furthermore, the administration of S. boulardii can significantly shorten infectious diarrhea in children, ${ }^{75,76}$ and the incidence of tube-fed-associated diarrhea in enterally fed patients decreases with $S$. boulardii administration. ${ }^{77-80}$

\section{S. boulardii - mechanisms of action}

There are several different effects induced by $S$. boulardii, both during a dysbiotic situation and in the prevention of dysbiosis (Table 1). ${ }^{69}$ Most of these effects are also cataloged in a 
recent review. ${ }^{81}$ Various mechanisms of action, outlined in what follows, have an influence on the microbial population (effects on the microbiota to be described in "The effect of S. boulardii on the microbiota") by directly or indirectly improving the growth environment for beneficial microbiota.

\section{General immune stimulation}

It is well known that yeast cells are an excellent source of $\beta(1,3)$ D-glucan. $\beta$-Glucans are fungal wall components that act as "biological response modifiers" due to their ability to activate the immune system. ${ }^{82,83}$ Glucans bind to specific receptors on dendritic cells (dectin-1) as well as to receptors on innate immune cells (eg, Toll-like receptors, complement receptor-3). ${ }^{84,85}$

A general immune stimulation is of advantage to the host, enabling the destruction of pathogens at an early stage. This yeast-mediated effect is particularly important as a preventive measure in a healthy situation - keeping the microbial environment in status quo - ensuring the bioreactor runs smoothly.

\section{Anti-inflammatory and antisecretory action}

The level of inflammation during diarrheic dysbiosis varies, depending also on the cause of the dysbiosis.

In patients with chronic idiopathic diarrhea, no leukocytes were detected within the fecal mucus layer, indicating the absence of a local cellular inflammatory response. ${ }^{18}$ Yet there are many situations when diarrhea is associated with inflammation. The inflammatory response is elicited by bacteria, which manage a direct contact to the mucosa, due to a destabilized mucus layer, and infiltrate the tissue. In response, an increased number of leukocytes migrate into the intestinal lumen to hinder bacterial infection.

Inflammatory effects, along with the symptomatic consequences of diarrhea, and cramping, do have their role in reducing infection, but the attempts to get rid of possibly lethal invaders also open the door to new infections, eg, by making the mucus layer less viscous and thus more permeable for microbes.

Many different studies demonstrate that $S$. boulardii elicits, also via secreted factors, pronounced anti-inflammatory and antisecretory effects by affecting key signaling pathways in intestinal host cells, such as the NF- $\mathrm{KB}$ and the MAP kinase pathways, which regulate the tight junction barrier as well as inflammation. ${ }^{86-90}$ The antisecretory properties of $S$. boulardii regarding water and electrolyte secretion were also demonstrated in additional studies. ${ }^{91-94}$

Reducing inflammation and secretion has a clear symptomatic advantage, and goes along with a faster recovery of the microbiota by offering an intestinal environment more like that during healthy conditions.

\section{Prebiotic effect}

The cell wall material of $S$. boulardii is composed of glucans, mannoproteins, and chitin, which serve as excellent substrates for microbial fermentation, especially for various SCFA producers. This helps explain the increase in butyrate and other SCFA produced within the colon after S. boulardii administration. ${ }^{95,96}$

In a long-term in vitro rumen simulation, both living and autoclaved S. boulardii significantly stimulated SCFA production, with no major differences between the treatments, ${ }^{97}$ suggesting a prebiotic effect of the yeast. Further studies are necessary to evaluate the extent of this effect in a clinical situation.

\section{Trophic effect on enterocytes}

Moreover, S. boulardii is able to synthesize and secrete polyamines. These polyamines can be absorbed by enterocytes and have a positive effect on their maturation as they play an important role in cell proliferation and differentiation. Furthermore, polyamines enhance the expression of intestinal enzymes. ${ }^{98-100}$

Table I Mechanisms of action of Saccharomyces boulardii CNCM I-745

\begin{tabular}{|c|c|c|c|}
\hline $\begin{array}{l}\text { Probiotic: creation of a } \\
\text { favorable microbiotic } \\
\text { environment }\end{array}$ & $\begin{array}{l}\text { Mucus protection; } \\
\text { elimination of bacterial } \\
\text { toxins, pathogen binding }\end{array}$ & $\begin{array}{l}\text { Possible prebiotic (substrate for } \\
\text { beneficial microbiota) effect and } \\
\text { stimulation of digestive enzymes }\end{array}$ & $\begin{array}{l}\text { General immune stimulation; } \\
\text { anti-inflammatory and } \\
\text { antisecretory action }\end{array}$ \\
\hline In case of dysbiosis & $\begin{array}{l}\text { Protection against pathogens } \\
\text { and their toxins; regeneration } \\
\text { of mucosal cells }\end{array}$ & $\begin{array}{l}\text { Regeneration and stabilization } \\
\text { of healthy microbiota; improved } \\
\text { enzymatic function of mucosal cells }\end{array}$ & $\begin{array}{l}\text { Reduction of secretory water } \\
\text { and electrolyte loss; reduction of } \\
\text { inflammation }\end{array}$ \\
\hline Preventive action & $\begin{array}{l}\text { Protection against pathogens } \\
\text { and their toxins }\end{array}$ & $\begin{array}{l}\text { Stabilization of healthy microbiota; } \\
\text { improved enzymatic function of } \\
\text { mucosal cells }\end{array}$ & $\begin{array}{l}\text { General healthy stimulation of } \\
\text { the immune system }\end{array}$ \\
\hline
\end{tabular}


Elimination of bacterial toxins, pathogen binding, and growth inhibition of microbial pathogens

$S$. boulardii produces factors that neutralize bacterial toxins and modulate host cell signaling pathways implicated in proinflammatory response during bacterial infection. ${ }^{53}$ For example, $S$. boulardii releases a protease that cleaves C. difficile toxins; ${ }^{101}$ also, S. boulardii can inactivate cholera toxin ${ }^{102}$ and dephosphorylate lipopolysaccharides from Escherichia coli O55B5. ${ }^{103}$

In addition, a direct binding to some pathogens is possible: strains of E. coli, Salmonella typhimurium, and S. typhi adhere to the surface of S. boulardii, thus preventing adhesion to and invasion of the host. ${ }^{104-106}$ Moreover, $S$. boulardii can inhibit the growth of a number of microbial pathogens like S. typhimurium ${ }^{107}$ and C. albicans. ${ }^{108}$

\section{Physical barrier effect and colonization resistance}

The presence of an intact mucus layer is pivotal to the protection of the intestinal mucosa against bacterial infiltration. ${ }^{15}$

It can be hypothesized that the sticky outer mucus surface offers the opportunity for $S$. boulardii to grow and build protective interlaced layers, making it even more difficult for pathogenic strains to reach the mucosa. ${ }^{19}$

In the healthy situation, commensals have been shown to limit pathogen colonization by competing for metabolites, thereby leading to "colonization resistance." 109 Similarly, S. boulardii - by its mere presence and/or its metabolic activity - may hinder potentially harmful bacteria from occupying a niche at the exposed mucosa. At the same time, $S$. boulardii itself is not competitive enough to keep this position for long, once habitual/essential bacteria regenerate. Yet its makeshift function may give the host further opportunities to rebuild the mucus layer by reducing the pressure from the potentially harmful microbiota. Studies are needed to verify this hypothesis.

\section{The effect of S. boulardii on the microbiota Overview}

Through its multiple mechanisms of actions, $S$. boulardii causes a faster reestablishment of a healthy microbiome following dysbiosis. This has been demonstrated in several human studies as well as in several animal models (Tables 2 and 3).

The effects of $S$. boulardii (most, if not all, studies on strain CNCM I-745) were studied mainly by analysis of the feces - this gives a rather accurate picture of the lower colon; however, the microbial situations in the less densely populated upper intestinal sections have not been studied in relation to the influence of $S$. boulardii.

Feces are inhomogeneous by nature, with different bacteria localized within the core than within the fecal mucus. Unfortunately, not all studies have taken this fact into account, and this may have led to slightly differing results.

\section{Nonclinical studies}

To examine the effects of $S$. boulardii in antibiotic-induced diarrhea, two studies were performed in a human microbiotaassociated mouse model, ${ }^{58,137}$ and one study used a Syrian hamster model. ${ }^{136}$ All three studies examined the microbiota before, during, and after antibiotic treatment. No antibiotic controls were applied to study the effect of $S$. boulardii in the healthy situation.

The common results were that treatment of $S$. boulardii did not have any significant effects on the healthy microbial composition. However, following antibiotic treatment, S. boulardii caused a significantly more rapid recovery of the normal intestinal microbiota.

Additionally, the effects of $S$. boulardii in obese, type 2 diabetic $\mathrm{db} / \mathrm{db}$ mice were studied. ${ }^{111}$ For this, a prior publication also needs to be considered, which describes the altered microbiota of obese, type 2 diabetic $\mathrm{db} / \mathrm{db}$ mice compared with normal mice. ${ }^{110}$ Altogether, it can be derived that the treatment of S. boulardii renders the microbiota of the obese, type 2 diabetic $\mathrm{db} / \mathrm{db}$ mice more "normal," corresponding to the observed reduction of the low-grade inflammation and fat mass (Table 2). ${ }^{111}$

\section{Clinical studies}

The overview of clinical studies is explained in Table 3.

\section{Effects of S. boulardii on the healthy human microbiome}

Two studies observed the effects of $S$. boulardii on the fecal microbial composition of healthy children/healthy volunteers. Whereas one study ${ }^{112}$ found a massive reduction of culturable E. coli within feces of children treated with $S$. boulardii, another study ${ }^{113}$ did not find any differences in the predominant fecal microbiota with PCR (polymerase chain reaction) analysis. Also culture-based techniques did not find significant changes in the microbiota in healthy controls receiving $S$. boulardii. ${ }^{114}$

DNA isolation from feces, followed by 16S rRNA gene PCR amplification and denaturing gradient gel electrophoresis for fingerprinting did not detect any universal changes in the fingerprints of volunteers treated with S. boulardii. ${ }^{115}$ 
Table 2 Nonclinical studies regarding the influence of the administration of Saccharomyces boulardii CNCM I-745 on the composition of the intestinal microbiota

\begin{tabular}{|c|c|c|}
\hline Study & Model & Effects of $S$. boulardii on microbiota (and some other results) \\
\hline Philippe-Taine ${ }^{136}$ & $\begin{array}{l}\text { Syrian hamster model } \\
-4 \times 10^{10} \mathrm{CFU} \text { S. boulardii/kg/d; } 5 \text { hamsters; day I-12 } \\
\text { - control hamsters; day I-12 } \\
\text { in both groups: I } \times \text { clindamycin, I hour after } \\
\text { aforementioned treatment on day I } \\
\text { Feces analysis by aerobic bacterial culture until day } 18\end{array}$ & $\begin{array}{l}\text { No effects of S. boulardii on healthy aerobic flora } \\
\text { Effects by S. boulardii on aerobic flora: } \\
\text { - decrease in the amplitude of antibiotic-induced changes } \\
\text { - reduction of resistant streptococci, Enterobacteriaceae, Candida } \\
\text { - more rapid recovery of basal level of staphylococci }\end{array}$ \\
\hline Barc et $\mathrm{al}^{58}$ & $\begin{array}{l}\text { Human microbiota-associated mouse model } \\
\text { A 7-day (day I-7) oral treatment with amoxicillin- } \\
\text { clavulanic acid: } \\
\text { - Day I-14: S. boulardii }\left(5 \times 10^{8} \mathrm{CFU} / \mathrm{d}\right), 6 \text { mice } \\
\text { - Day I-I4: water (control), } 6 \text { mice } \\
\text { Feces analysis before, during, and after antibiotic } \\
\text { treatment up to day } 29 \\
\text { FISH with group-specific } 16 \mathrm{~S} \text { rRNA probes + flow } \\
\text { cytometry }\end{array}$ & $\begin{array}{l}\text { Antibiotic treatment: increase of Enterobacteriaceae and Bacteroides; } \\
\text { dramatic decrease of Clostridium coccoides-Eubacterium rectale } \\
\text { (Lachnospiraceae) } \\
\text { S. boulardii: Significantly more rapid recovery of normal intestinal } \\
\text { microbiota in the } S \text {. boulardii-treated mice compared with the control } \\
\text { mice }(P=0.05)\end{array}$ \\
\hline Collignon et al ${ }^{137}$ & $\begin{array}{l}\text { Human microbiota-associated mouse model } \\
\text { A 7-day (day I-7) oral treatment with amoxicillin- } \\
\text { clavulanic acid: } \\
\left.\text { - Day I-I4: S. boulardii ( } 5 \times 10^{8} \mathrm{CFU} / \mathrm{d}\right), 6 \text { mice } \\
\text { - Day I-I4: control, } 6 \text { mice } \\
\text { Feces analysis before, during, and after antibiotic } \\
\text { treatment up to day } 29 \\
\text { FISH with group-specific I6S rRNA probes: mainly } \\
\text { flow cytometry }\end{array}$ & $\begin{array}{l}\text { Antibiotic treatment: disrupted intestinal microbiota: } C \text {. coccoides } \\
\text { group (Lachnospiraceae) decreased; Bacteroides group increased; } \\
\text { Enterobacteriaceae became detectable } \\
\text { S. boulardii: more rapid restoration of the balance of the dominant } \\
\text { anaerobic microbiota } \\
\text { Other S. boulardii effects: downregulation of antigen-presenting } \\
\text { function of dendritic cells (anti-inflammatory effect) }\end{array}$ \\
\hline $\begin{array}{l}\text { Everard et al;" }{ }^{\prime \prime \prime} \\
\text { Geurts et al }\end{array}$ & $\begin{array}{l}\text { Obese, type } 2 \text { diabetic } \mathrm{db} / \mathrm{db} \text { mice: } \\
\text { - } 4 \text { weeks } \mathrm{S} \text {. boulardii, } 15 \text { mice } \\
\text { - } 4 \text { weeks saline (control), } 15 \text { mice } \\
\text { DNA isolation, I6S rRNA gene PCR amplification } \\
\text { followed by sequencing }\end{array}$ & $\begin{array}{l}\mathrm{db} / \mathrm{db} \text { mice: significant decrease in Bacteroidetes, significant increase of } \\
\text { Firmicutes and Proteobacteria compared with lean mice } \\
\text { S. boulardii: increase in Bacteroidetes (increase in Bacteroidaceae, } \\
\text { decrease in Porphyromonadaceae) and decrease in Firmicutes } \\
\text { (including Ruminococcus), Proteobacteria, and Prevotella. } \\
\text { Other S. boulardii effects: reduction of hepatic steatosis, low-grade } \\
\text { inflammation, and fat mass, increase of cecum weight and cecum } \\
\text { tissue weight }\end{array}$ \\
\hline
\end{tabular}

Abbreviations: CFU, colony forming units; FISH, fluorescence in situ hybridization; PCR, polymerase chain reaction.

These findings can be confirmed using fluorescence in situ hybridization (FISH) probing - the structural organization of fecal microbiota in healthy subjects was stable and unaffected by $S$. boulardii. ${ }^{18,49}$

Also, 16S rRNA gene pyrosequencing did not reveal any substantial modification by $S$. boulardii. ${ }^{116}$

Accordingly, and in correspondence with the nonclinical results, $S$. boulardii does not seem to alter the composition of the healthy microbiota, except perhaps for a certain reduction of the rather minor prevalence of Enterobacteriaceae like E. coli. ${ }^{112}$

This appears reasonable. In a healthy situation, S. boulardii is certainly not competitive enough to displace the healthy microbiota, and the number of $S$. boulardii during healthy intestinal passage may possibly not rise above the administered dose.
On their way through the healthy intestinal tract, most yeast cells become digested. A preliminary unpublished investigation on ten healthy students pointed toward slightly reduced total bacterial fecal numbers, when these students were administered $S$. boulardii, possibly indicating slightly more efficient overall food consumption, with reduced chances of bacterial growth at the stage of excretion (data not shown).

Altogether, the dysbiosis prevention (Table 1) is plausibly derived from the aforementioned ("S. boulardii - mechanisms of action") mechanisms of action of S. boulardii.

Both the yeast cell wall components stemming from the digested yeast cells as well as those yeast cells that managed to pass the acid stress of the stomach alive and begin to prosper within the intestine, unfold multiple preventive actions. 


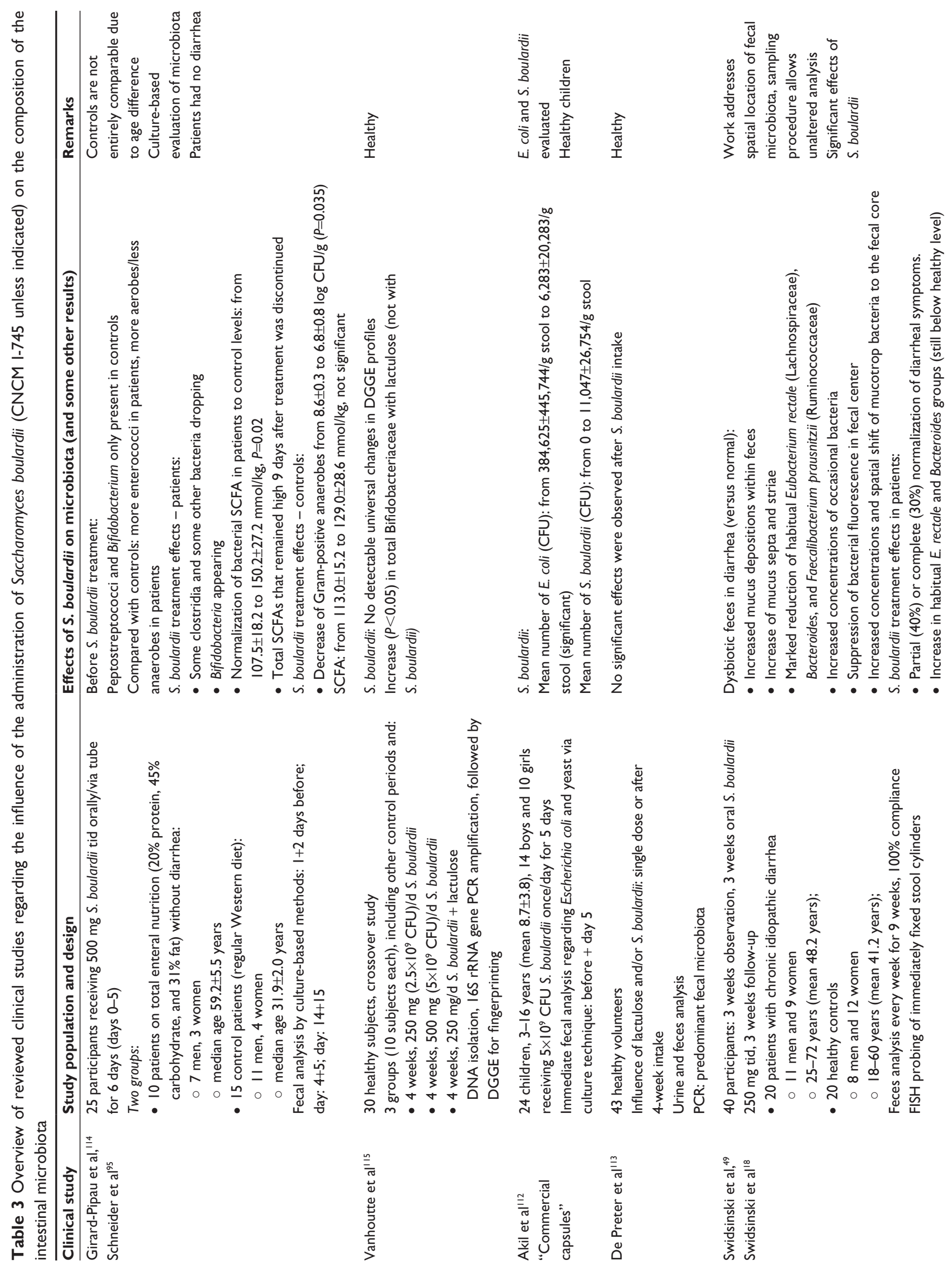



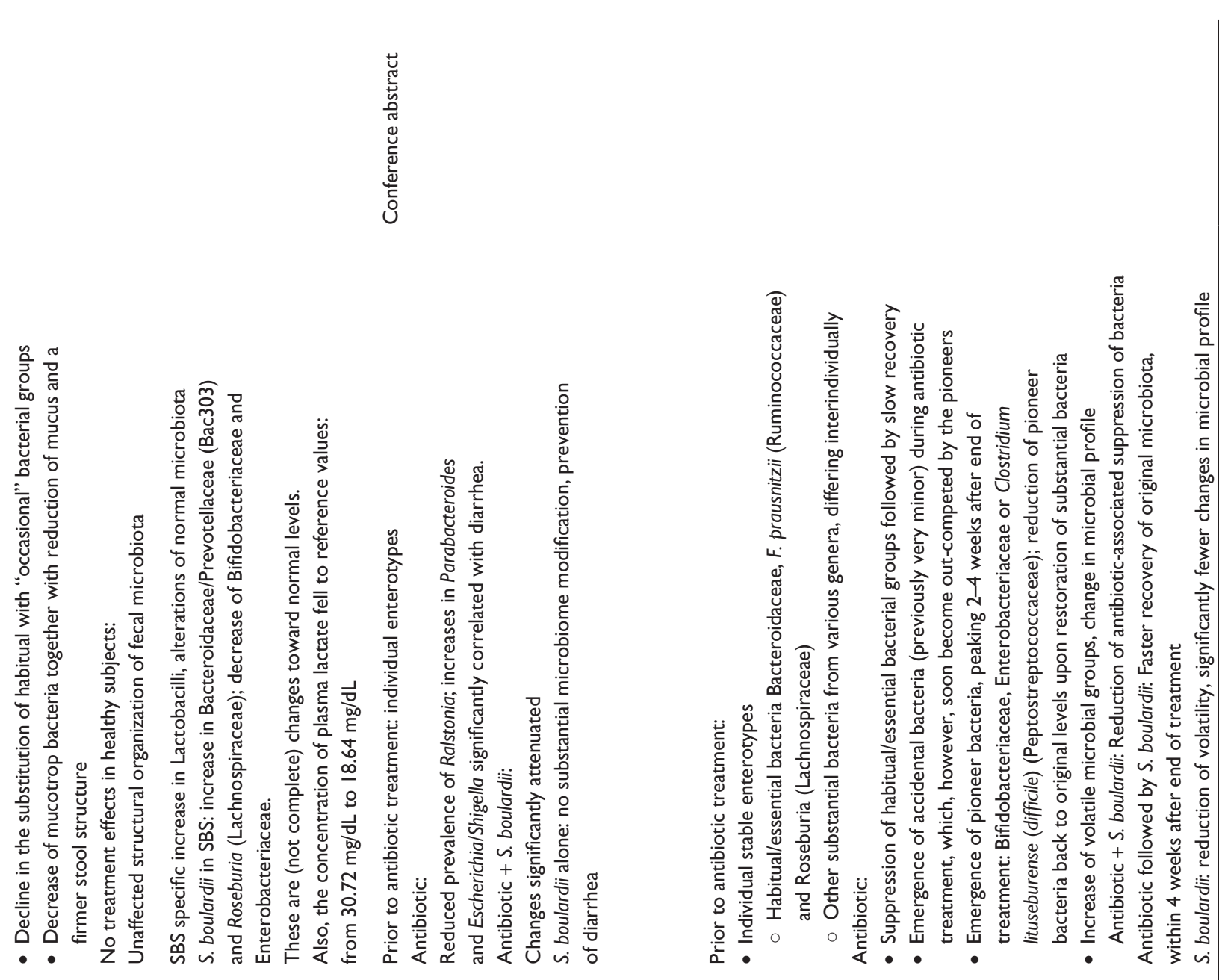
Owing to the already well-functioning intestinal microbiome in a healthy human, the preventive effects of $S$. boulardii become apparent only during special challenges, eg, during exposure to pathogens eliciting traveler's diarrhea, ${ }^{74}$ or in the prevention of antibiotic-induced diarrhea. ${ }^{71}$ However, these effects are indicative that without having any pronounced influence on the composition of the healthy microbiome $-S$. boulardii is capable of protecting this microbial community.

\section{Effects of S. boulardii during dysbiosis}

In a culture-based evaluation of the effects of $S$. boulardii in patients on (low-fiber) total enteral nutrition, the yeast improved the overall microbial fecal composition - even in patients who were not suffering from diarrhea. ${ }^{95,114}$ Before treatment, many more different bacterial strains could be isolated from the feces of the healthy controls as compared with the feces of patients, indicating a somewhat reduced diversity in the patients. S. boulardii led to a number of changes of the microbiota, eg, reducing counts of certain bacteria, some of which recovered after stopping the treatment, while others did not. This included the reduction of several clostridial strains. Also, there seemed to be an overall reduction of Gram-positive anaerobes in the controls.

In view of the culture-based evaluation of the microbiota, the results must be interpreted with caution. It is possibly more interesting that the authors noted a significant increase in SCFA after 6 days of S. boulardii administration. In particular, butyrate and propionate increased significantly within the feces of the tube-fed patients. In the healthy controls too, there was a slight increase in SCFA, but it was nonsignificant.

With the current understanding, it can be assumed that the increase in SCFA in the patient group is an indirect consequence of the $S$. boulardii-induced return of the gut microbiota to a more normal composition.

A major contribution has been the study of patients with chronic idiopathic diarrhea as compared with healthy controls. ${ }^{18,49}$ This study used an advanced method of detection - FISH probing of immediately fixed stool cylinder specimens along with a spatial analysis of the microbiota, allowing a differentiation between mucus layer and central fecal microbiota. Accordingly, the fecal ecosystem is accurately described both in the healthy situation and during diarrheic dysbiosis. The latter caused a drastic increase of

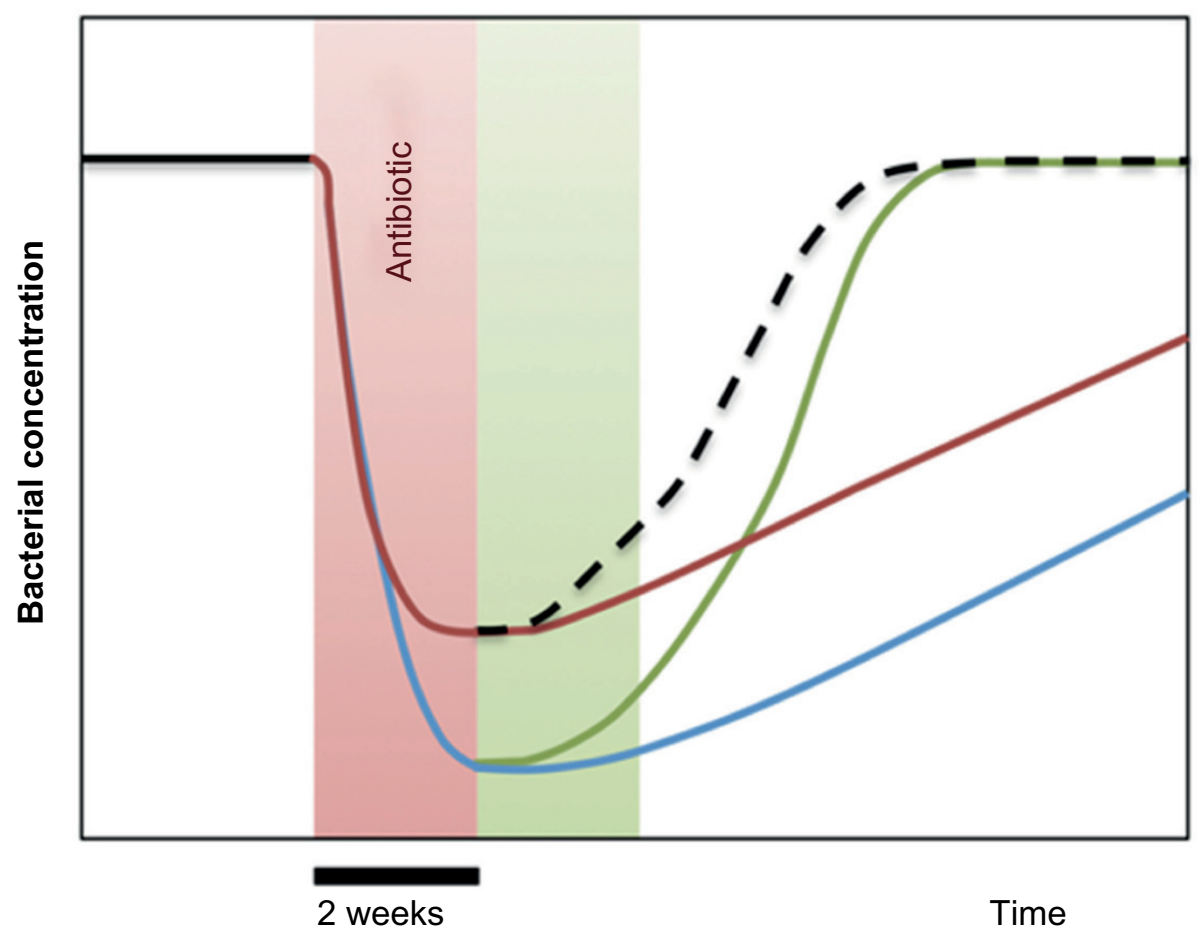

Figure 2 Generalized scheme of the effects of antibiotic dysbiosis on habitual/essential bacteria and other substantial bacteria.

Notes: Upon a 2-week antibiotic treatment (red area), the main microbial population suffers an abrupt decrease (blue line). Saccharomyces boulardii administered during antibiotic treatment (red area; red line) can reduce this decline by protecting the microbiota. If instead S. boulardii is administered following antibiotic treatment (green area; green line), S. boulardii can support a faster regeneration of the microbial population. Accordingly, the optimum would be a combination of both, a treatment with $\mathrm{S}$. boulardii during and following antibiotic treatment. This is represented by the hypothetical black dotted line, which was derived from the other lines. The worst-case scenario is no $S$. boulardii treatment (blue line). Pioneer bacteria and accidental bacteria are excluded. 
the mucus layer (assumable along with a lower viscosity and thus higher permeability) and profound changes in the composition of the microbiota. Almost all parameters typical of diarrhea improved significantly with $S$. boulardii treatment, and most changes persisted after cessation of therapy. This went along with a partial $(40 \%)$ or complete $(30 \%)$ normalization of diarrheal symptoms.

In a study with 14 Short Bowel Syndrome (SBS) adult patients on long-term parenteral nutrition, S. boulardii also partially rendered the microbiota more similar to the healthy controls. Also here, FISH probing of immediately fixed stool cylinder specimens was used as methodology. ${ }^{117}$

A study with 60 women (30 in preanalysis, 60 in soon to be published final analysis) treated for bacterial vaginosis examined the effects of antibiotic therapy alone, or contemporaneously with $S$. boulardii treatment, or followed by $S$. boulardii treatment. ${ }^{118,119}$ Again, FISH analysis of fixated stool cylinders was used to examine the microbiota. Before treatment, stable enterotypes were observed; however, the antibiotics caused a suppression of the habitual/essential (most common) bacteria as well as other substantial bacterial groups. S. boulardii could reduce the antibiotic-associated suppression of these bacteria if administered simultaneously. If administered following antibiotic treatment, $S$. boulardii led to a significantly faster recovery of original microbiota. Additionally, S. boulardii led to less pre-postmismatches of the microbial population. In the absence of $S$. boulardii, the antibiotic treatment caused significantly more population differences (compared with before treatment) than if $S$. boulardii had been administered.

A generalized scheme of the effects of $S$. boulardii is depicted in Figure 2. From the curves we conclude that the optimal treatment would be to administer $S$. boulardii simultaneously to the antibiotic treatment, plus subsequently for at least 2 weeks.

In a different study, antibiotic-induced dysbiosis and its treatment with $S$. boulardii were studied in healthy volunteers, using 16S rRNA gene pyrosequencing for bacterial genera detection. ${ }^{116}$ Prior to treatment, individual enterotypes could be identified. The antibiotic induced significant alterations of the microbial composition, which were significantly attenuated by $S$. boulardii. In a setting where $S$. boulardii was administered in parallel to the antibiotic, the associated diarrhea could be prevented $(P<0.05)$.

Altogether, several small but well-designed studies have demonstrated that $S$. boulardii can lead to a faster recovery from diarrheic dysbiosis with regard to the microbial population, as well as to a certain protection of dysbiosis if administered preventively during antibiotic therapy.

\section{Specific effects of S. boulardii on mucus and microbiota}

Table 4 summarizes the proposed effects of $S$. boulardii on specific microbial subgroups. The following subheadings match the main groups of Table 4 .

The healthy fecal microbiota can be divided into habitual/essential bacterial groups, usually present in all healthy humans and other individual substantial bacteria. Other occasional bacterial are present only in minor proportions.

Depending on the individual enterotype, the amount of specific bacteria within the feces can vary (healthy human prevalence in \% is presented in Table 4). During dysbiosis, the proportion of different microbial strains changes, and so does the thickness and consistency of the mucus. In the following, the specific effects of $S$. boulardii on the mucus and the major bacterial groups during dysbiosis and recovery are summarized.

\section{Mucus}

It is known that certain bacteria, especially certain pathogens, feed on mucin oligosaccharides. ${ }^{120}$ This way they are capable of reducing the mucus integrity, leading to increased porosity and maceration, thereby opening a path for themselves and other bacteria to reach the epithelial cells.

Thus, a polymicrobial infection, sustained by a broken mucus barrier, is characteristic for inflammatory conditions like ulcerative colitis. ${ }^{121}$

A study on chronic idiopathic diarrhea has shown an increase in fecal mucus thickness with more watery stools. ${ }^{18,49}$ However, as the fecal mucus layer contained many septae and was often disrupted, the increased thickness $(265 \pm 266 \mu \mathrm{m})$ of the mucus did not lead to enhanced stability. Upon $S$. boulardii treatment, the mucus layer got reduced to $96 \pm 118 \mu \mathrm{m}$ $(P=0.002)$. After $S$. boulardii treatment was stopped, a reincrease of the mucus layer was observed.

\section{Bacteroidetes - Bacteroidia - Bacteroidales}

Bacteroidales are Gram-negative obligate anaerobic rods, playing a fundamental role in the processing of complex molecules to simpler ones within the intestinal tract. ${ }^{122}$ Bacteroidaceae (genus: Bacteroides) and Prevotellaceae (genus: Prevotella) have a prominent prevalence within the healthy colon and can be assigned to the habitual/essential microbiota. The Porphyromonadaceae (including Porphyromonas and Parabacteroides) are mostly of lower prevalence (Table 4). 
Table 4 Bacterial groups in the feces and their major changes in prevalence due to (mostly antibiotic induced) dysbiosis as well as Saccharomyces boulardii (mostly strain CNCM I-745) treatment

\begin{tabular}{|c|c|c|c|c|}
\hline $\begin{array}{l}\text { Intestinal bacterial group } \\
\text { with important fecal } \\
\text { prevalence } \\
\text { Exemplary on genus level }\end{array}$ & $\begin{array}{l}\text { Examples of shape } \\
\text { Commonly used } \\
\text { probes }^{\mathrm{a}, 141} \\
\text { "Alternate group names" }\end{array}$ & $\begin{array}{l}\text { Gram stain; } \\
\text { Aerobic/anaerobic } \\
\text { Fermentation products }\end{array}$ & $\begin{array}{l}\text { Healthy human fecal } \\
\text { prevalence in } \%^{\mathrm{b}}\end{array}$ & $\begin{array}{l}\text { Significant population } \\
\text { changes in studies } \\
\text { with S. boulardii (Sb) }\end{array}$ \\
\hline $\begin{array}{l}\text { Phylum: Bacteroidetes } \\
\text { Class: Bacteroidia } \\
\text { Order: Bacteroidales }\end{array}$ & $\infty \infty^{\infty}$ & $\begin{array}{l}\text { Gram-negative nonmotile } \\
\text { rods, obligate anaerobes }\end{array}$ & $\begin{array}{l}41.0-47.7^{142} \\
59.2^{51} \\
36.8 \pm 16^{143}\end{array}$ & \\
\hline $\begin{array}{l}\text { Family: Bacteroidaceae } \\
\text { - Bacteroides }\end{array}$ & $\begin{array}{l}\text { Bfra602-Bdis656 } \\
\text { Bac303c }\end{array}$ & Acetate, succinate & $\begin{array}{l}22.7^{51} \\
I I \pm 7.8^{144}(\text { Bfra }) \\
8.5 \pm 7 . I^{134}(\text { Bac303) } \\
20^{145}(\text { Bfra602-Bdis656) } \\
31.7^{51} \\
4.4 \pm 4.9^{144}\end{array}$ & $\begin{array}{l}\text { Less reduction during } \\
\text { antibiotic treatment with } \\
S b^{118,119} \\
\uparrow \text { Improved recovery } \\
\text { with } S b^{18,117-119}\end{array}$ \\
\hline $\begin{array}{l}\text { Porphyromonadaceae } \\
\text { - Porphyromonas } \\
\text { - Parabacteroides }\end{array}$ & & & $3.6^{51}$ & $\begin{array}{l}\downarrow \text { Reduction back to } \\
\text { normal levels with } S b^{116}\end{array}$ \\
\hline $\begin{array}{l}\text { Firmicutes } \\
\text { Clostridia } \\
\text { Clostridiales }\end{array}$ & $\underbrace{\infty 000000}_{\infty}$ & $\begin{array}{l}\text { Gram-positive rods or cocci, } \\
\text { obligate anaerobes }\end{array}$ & $\begin{array}{l}\text { Firmicutes: } 49.4-54.8^{142} \\
34.7^{51}\end{array}$ & \\
\hline $\begin{array}{l}\text { Lachnospiraceae } \\
\text { - Blautia } \\
\text { - Coprococcus } \\
\text { - Lachnoclostridium } \\
\text { - Roseburia }\end{array}$ & $\begin{array}{l}\text { Erec482 } \\
\text { "Clostridium coccoides- } \\
\text { Eubacterium rectale group" } \\
\text { Clostridium cluster } \\
\text { XIVa and XIVb } \\
\text { "Roseburia group" }\end{array}$ & $\begin{array}{l}\text { SCFA, acetate, formate, } \\
\text { ethanol, } \mathrm{H}_{2} \text {, lactate, succinate }\end{array}$ & $\begin{array}{l}7.5^{51} \\
29 \pm 12^{144} \\
7-28^{143} \\
28.0 \pm 11.3^{134} \\
29^{145}\end{array}$ & $\begin{array}{l}\text { Less reduction during } \\
\text { antibiotic treatment with } \\
S b^{118,119} \\
\uparrow \text { Improved recovery } \\
\text { with } S b^{18,58,117-119,137}\end{array}$ \\
\hline $\begin{array}{l}\text { Ruminococcaceae } \\
\text { - Faecalibacterium prausnitzii } \\
\text { - Ruminococcus bromii } \\
\text { - Ruminococcus callidus } \\
\text { - Ruminiclostridium } \\
\text { [Clostridium] leptum }\end{array}$ & $\begin{array}{l}\text { Fprau } \\
\text { Clep } 866 \text { (Rbro730+ } \\
\text { Rfla729+ Rcal733+ } \\
\text { Fprau645) } \\
\text { Cvir I4I4, Edes } 635 \\
\text { S-G-Clept-1240 } \\
\text { "C. leptum group; } \\
\text { Clostridium cluster IV" }\end{array}$ & $\begin{array}{l}\text { Butyrate, acetate, lactate, } \\
\text { formate, } \mathrm{H}_{2}\end{array}$ & $\begin{array}{l}6-39^{143} \\
26.7( \pm 7)^{134} \\
15 \pm 10^{144}(\mathrm{~S}-\mathrm{G}-C l e p t- \\
1240) \\
6.3^{51} \\
15.4 \pm 7.2^{134} \text { (Fprau645) }\end{array}$ & $\begin{array}{l}\text { Less reduction during } \\
\text { antibiotic treatment with } \\
S b^{118,119} \\
\uparrow \text { Improved recovery } \\
\text { with } S b^{118,119}\end{array}$ \\
\hline $\begin{array}{l}\text { Peptostreptococcaceae } \\
\text { - Romboutsia [Clostridium] } \\
\text { lituseburensis } \\
\text { - Peptoclostridium } \\
\text { [Clostridium] difficile }\end{array}$ & $\begin{array}{l}\text { Clit I } 35 \\
\text { "C. lituseburense group" }\end{array}$ & Butyrate, acetate & & $\begin{array}{l}\text { Increase during } \\
\text { diarrhea }^{18} \\
\text { Pioneer species }^{118,119}\end{array}$ \\
\hline $\begin{array}{l}\text { Clostridiales Family XI. } \\
\text { Incertae Sedis } \\
\text { - Anaerococcus } \\
\text { - Finegoldia } \\
\text { - Peptoniphilus }\end{array}$ & & & $14.8^{51}$ & \\
\hline $\begin{array}{l}\text { Clostridiaceae } \\
\text { - Clostridium histolyticum }\end{array}$ & $\begin{array}{l}\text { Chis I } 50 \\
\text { "Clostridium cluster I } \\
\text { and II" }\end{array}$ & & & $\begin{array}{l}\downarrow \text { Reduction back to } \\
\text { normal levels with } \\
S b^{118,119}\end{array}$ \\
\hline $\begin{array}{l}\text { Eubacteriaceae } \\
\text { - Eubacterium cylindroides }\end{array}$ & Ecyl387 & Butyrate & $1.1 \pm 1.9^{134}$ & $\begin{array}{l}\text { Increase during } \\
\text { diarrhea }^{18}\end{array}$ \\
\hline $\begin{array}{l}\text { Firmicutes } \\
\text { Negativicutes } \\
\text { Selenomonadales }\end{array}$ & $\infty$ & Gram-negative & & \\
\hline
\end{tabular}


Table 4 (Continued)

\begin{tabular}{|c|c|c|c|c|}
\hline $\begin{array}{l}\text { Intestinal bacterial group } \\
\text { with important fecal } \\
\text { prevalence } \\
\text { Exemplary on genus level }\end{array}$ & $\begin{array}{l}\text { Examples of shape } \\
\text { Commonly used } \\
\text { probes }^{\mathrm{a}, 141} \\
\text { "Alternate group names" }\end{array}$ & $\begin{array}{l}\text { Gram stain; } \\
\text { Aerobic/anaerobic } \\
\text { Fermentation products }\end{array}$ & $\begin{array}{l}\text { Healthy human fecal } \\
\text { prevalence in \% }\end{array}$ & $\begin{array}{l}\text { Significant population } \\
\text { changes in studies } \\
\text { with S. boulardii (Sb) }\end{array}$ \\
\hline $\begin{array}{l}\text { Veillonellaceae } \\
\text { - Dialister } \\
\text { - Megasphaera } \\
\text { - Veillonella }\end{array}$ & Veil223 & $\begin{array}{l}\text { Fermenting lactate } \rightarrow \\
\text { proprionate, acetate }\end{array}$ & $\begin{array}{l}3.5^{51} \\
15 \pm 10^{144} \\
1.3 \pm 1.3^{134}\end{array}$ & \\
\hline $\begin{array}{l}\text { Firmicutes } \\
\text { Bacilli } \\
\text { Lactobacillales }\end{array}$ & $\begin{array}{l}\underset{\infty 00000}{\infty 00000000} \\
.000\end{array}$ & $\begin{array}{l}\text { Gram-positive rods or cocci, } \\
\text { aerotolerant or facultative } \\
\text { anaerobes }\end{array}$ & & \\
\hline $\begin{array}{l}\text { Lactobacillaceae } \\
\text { - Lactobacillus }\end{array}$ & LabI58c & Lactic acid, ethanol, acetate & $1.8 \pm 1.4^{134}$ & $\begin{array}{l}\text { Increase in SBS } \\
\text { patients } 117\end{array}$ \\
\hline $\begin{array}{l}\text { Enterococcaceae } \\
\text { - Enterococcus } \\
\text { Streptococcaceae } \\
\text { - Streptococcus }\end{array}$ & LabI58c & & $\begin{array}{l}(\text { Labl58) } \\
0.6 \pm 0.8^{134}\end{array}$ & $\begin{array}{l}\text { Streptococcus: } \\
\text { Prevention of antibiotic- } \\
\text { associated peak by } \\
S b^{118,119}\end{array}$ \\
\hline $\begin{array}{l}\text { Actinobacteria } \\
\text { Actinobacteria }\end{array}$ & कृषि & $\begin{array}{l}\text { Gram-positive rods, } \\
\text { anaerobes }\end{array}$ & $1.94^{51}$ & \\
\hline $\begin{array}{l}\text { Bifidobacteriales } \\
\text { Bifidobacteriaceae } \\
\text { - Bifidobacterium }\end{array}$ & Bifl 64 & $\begin{array}{l}\text { Sometimes aerotolerant } \\
\text { Organic acids, SCFA }\end{array}$ & $\begin{array}{l}1.07^{51} \\
0-5^{143} \\
1.2-6^{146} \\
6.0 \pm 6.4^{144} \\
4.4 \pm 4.3^{134}\end{array}$ & $\begin{array}{l}\downarrow \text { Reduction back to } \\
\text { normal levels with } S b ;{ }^{117} \\
\text { Pioneer species } \\
118,119\end{array}$ \\
\hline $\begin{array}{l}\text { Coreobacteriales } \\
\text { Coriobacteriaceae } \\
\text { - Coriobacterium } \\
\text { - Consinella } \\
\text { - Atopobium } \\
\text { - Eggerthella }\end{array}$ & Ato291 & $\begin{array}{l}\text { Obligate anaerobes } \\
\text { Acetate, lactate ethanol, } \mathrm{H}_{2}\end{array}$ & $\begin{array}{l}<1 \\
4.9 \pm 4.2^{144} \\
1.7 \pm 2.3 \\
3.1 \pm 2.8^{134} \\
0,1-7^{146}\end{array}$ & \\
\hline $\begin{array}{l}\text { Proteobacteria } \\
\text { Gammaproteo-bacteria } \\
\text { Enterobacteriales }\end{array}$ & $\overbrace{\infty}=$ & $\begin{array}{l}\text { Gram-negative rods, } \\
\text { facultative anaerobes }\end{array}$ & $2.39^{51}$ & \\
\hline $\begin{array}{l}\text { Enterobacteriaceae } \\
\text { - Escherichia } \\
\text { - Shigella } \\
\text { - Enterobacter } \\
\text { - Salmonella } \\
\text { - Yersinia }\end{array}$ & $\begin{array}{l}\text { Ebac I } 790 \\
\text { Enter } 1432^{134}\end{array}$ & $\begin{array}{l}\text { Lactate, etc, } \\
\text { Nitrate } \rightarrow \text { nitrite }\end{array}$ & $0.1 \pm 0.1^{134}$ & $\begin{array}{l}\downarrow \text { Reduction back to } \\
\text { normal levels with } \\
\text { Sb; }{ }^{58,116-119,136,137} \\
\text { Diarrheic increase } \\
\text { especially in mucus; }{ }^{18} \\
\text { Pioneer species }{ }^{18,119}\end{array}$ \\
\hline $\begin{array}{l}\text { Alcaligenaceae } \\
\text { - Alcaligenes faecalis }\end{array}$ & Alc-476 & $\begin{array}{l}\text { Nitrate } \rightarrow \text { nitrite, } \\
\text { denitrifying }\end{array}$ & $1.14^{51}$ & \\
\hline $\begin{array}{l}\text { Campylobacteraceae } \\
\text { - Campylobacter }\end{array}$ & & & $0.92^{51}$ & \\
\hline $\begin{array}{l}\text { Verrucomicrobia } \\
\text { Verrucomicrobiae } \\
\text { Verrucomicrobiales }\end{array}$ & $\infty{ }^{\infty}$ & $\begin{array}{l}\text { Gram-negative rods, obligate } \\
\text { anaerobes }\end{array}$ & & \\
\hline $\begin{array}{l}\text { Verrucomicrobiaceae } \\
\text { - Akkermansia }\end{array}$ & Muc|437 & $\begin{array}{l}\text { Capsule-forming on mucin, } \\
\text { fermenting carbohydrates }\end{array}$ & $\begin{array}{l}\text { Prominent prevalence } \\
\text { in mucus }\end{array}$ & $\begin{array}{l}\text { Improved modulation } \\
\text { toward normal levels } \\
\text { with } S b^{18,118,119}\end{array}$ \\
\hline
\end{tabular}

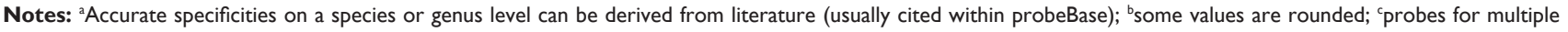
groups (check other groups as well). Detection by different methods: 1) culture techniques, ${ }^{136}$ 2) clonal sequencing, ${ }^{142}$ 3) pyrosequencing, ${ }^{51,116} 4$ ) $16 \mathrm{~S}$ rRNA dot blot hybridization, ${ }^{143}$ 5) I6S rRNA PCR, ${ }^{144}$ 6) FISH combined with flow cytometry, ${ }^{58,134,137}$ 7) FISH and microscopic counting of homogenized samples, ${ }^{145,146}$ 8) FISH and microscopic counting of immediately fixed stool cylinders. $18,49,117-119$

Abbreviations: SCFA, short chain fatty acids; SBS, short bowel syndrome; FISH, fluorescence in situ hybridization; PCR, Polymerase chain reaction; rRNA, ribosomal ribonucleic acid; Sb, S. boulardii. 
During ulcerative colitis, a strong reduction of the Bacteroidaceae/Prevotellaceae was observed. ${ }^{19}$

Interestingly, Bacteroidales are able to grow on mucin, and this can explain their mucosal colonization in IBD. ${ }^{123}$

As found in a clinical study, diarrhea was associated with a massive reduction in the combined Bacteroidaceae and Prevotellaceae (Bac303 probe $\left.{ }^{124}\right) .{ }^{18,49}$ During treatment with S. boulardii, their amount significantly increased, even though a full recovery to healthy levels could not be observed. Also, in patients with SBS Bacteroidaceae/ Prevotellaceae decreased, and upon S. boulardii treatment, their amount increased significantly toward more normal levels (no complete normalization). ${ }^{117}$ Similarly, following antibiotic-induced dysbiosis, Bacteroidaceae/Prevotellaceae strongly declined; this suppression was attenuated by $S$. boulardii. ${ }^{118,119}$ In another study on antibiotic-induced diarrhea, an increase of Parabacteroides was noted, and this change was attenuated with $S$. boulardii. ${ }^{116}$

\section{Firmicutes - Clostridia - Clostridiales}

Within the class of Clostridia, systematic reclassifications have taken place recently. Table 4 includes their most relevant families for the microbiota.

Also, the most prevalent fecal groups are discussed here:

\section{Lachnospiraceae}

Members of this family are also described as "Clostridium coccoides-Eubacterium rectale group", "Clostridium cluster XIVa and XIVb", or "Roseburia group". ${ }^{125-127}$

They are fermentative, often spore-forming obligate anaerobes, and are well known as major SCFA producers, ${ }^{126}$ although other fermentation products are possible.

As a major group within the human feces, they constitute between $7 \%$ and $29 \%$ (Table 4 ) of the fecal bacteria in a healthy situation.

\section{Ruminococcaceae}

Members of this family are also described as "Clostridium leptum group," "Clostridium cluster IV," "Faecalibacterium prausnitzii group," or “Ruminococcus group." ${ }^{125-127}$

Similarly to the Lachnospiraceae, they are fermentative, obligate anaerobes, and major butyrate producers; ${ }^{126}$ other fermentation products are acetate, lactate, formate, and hydrogen. In the healthy human, they constitute between $6 \%$ and 39\% (Table 4 ) of the fecal bacteria.

A reduction of Ruminococcaceae was described in Crohn's disease and ulcerative colitis patients. ${ }^{128}$ Indeed, F. prausnitzii, which has a very strong prevalence in the healthy, is extremely sensitive to intestinal disturbances, and thus, the undetectability of $F$. prausnitzii in stool samples is indicative of active Crohn's disease. ${ }^{19}$ Interestingly, antiinflammatory effects are linked to this bacterium. ${ }^{129,130}$

The prevalence of both Lachnospiraceae and Ruminococcaceae was reduced during idiopathic diarrhea. ${ }^{18,49}$ A statistically significant increase, although not to healthy levels, of the Lachnospiraceae could be observed due to S. boulardii. ${ }^{18,49}$ Similarly, in SBS patients, the Lachnospiraceae were reduced, and an increase could be observed with $S$. boulardii treatment. ${ }^{117}$

The reduction of these clostridial groups during diarrheic dysbiosis goes along with the observed decrease in SCFA; their increase upon treatment with $S$. boulardii is paralleled by an increase in SCFA.

\section{Firmicutes - Bacilli - Lactobacillales}

The Lactobacillales, including Lactobacillaceae, Enterococcaceae, and Streptococcaceae, only make up a minor portion of the microbiota within the healthy colon (Table 4). However, these groups can serve as starter cultures not only in food fermentation, but also during regeneration of the microbiota after dysbiosis - this is why members of the Lactobacillales are also widely used as probiotics. ${ }^{131-133}$

In patients with short bowel syndrome, a significant increase in the concentration of Lactobacilli was observed, with a tendency to decrease with the administration of S. boulardii. ${ }^{117}$

\section{Actinobacteria - Actinobacteria - \\ Bifidobacteriales - Bifidobacteriaceae}

Bifidobacteria can be considered equivalent to pioneer plants after clear-cutting, vastly increasing after dysbiosis, but giving up their makeshift position upon regeneration of the entire microbiome. As such, they are excellent indicator microbes to identify dysbiotic situations, eg, after a stroke. ${ }^{42}$

Several studies have shown an increase in Bifidobacteriaceae during different types of diarrhea. ${ }^{18,117-119}$ A return to healthy levels after $S$. boulardii treatment has been demonstrated in SBS patients. ${ }^{117}$

$S$. boulardii concomitant with antibiotics reduced the antibiotic-associated suppression also of Bifidobacteriaceae, resulting in a slightly stronger interim peak typical of pioneer bacteria. $^{118,119}$

\section{Proteobacteria - Gammaproteobacteria - Enterobacteriales - Enterobacteriaceae}

Many intestinal Enterobacteriaceae can be considered mucotrop, with higher numbers within or close to the fecal 
mucus layer. However, the central feces also contains (different) Enterobacteriaceae in low abundance, with about $0.1 \%$ prevalence within the healthy human feces. ${ }^{134}$ Enterobacteriaceae are facultative anaerobes, and can, during anaerobic conditions, as those in the intestine, live on the fermentation of various carbohydrates to lactate and other metabolites. The ability of most Enterobacteriaceae to also gain energy by dissimilatory nitrate reduction gives them a special advantage during inflammation, which makes increased amounts of nitrate available together with an excess supply of undigested carbohydrates. ${ }^{120}$

A special case is the use of the respiratory electron acceptor tetrathionate for anaerobic ethanolamine degradation, which confers a growth advantage on certain Salmonella strains. Tetrathionate develops during infection from the oxidation of endogenous sulfur compounds by reactive oxygen species. ${ }^{135}$

Altogether, studies have observed a pioneer-type increase in the number of Enterobacteriaceae during dysbiosis, ${ }^{118,119}$ particularly in the mucus layer. ${ }^{18}$ Especially problematic is the increase of pathogenic Enterobacteriaceae such as $S$. typhimurium or certain E. coli strains.

In the studies with $S$. boulardii, it was found that $S$. boulardii led to a beneficial reduction of Enterobacteriaceae ${ }^{58,116-119,136,137}$ back to healthy levels.

\section{Verrucomicrobia - Verrucomicrobiae - Verrucomicrobiales - Verrucomicrobiaceae}

Akkermansia is a bacterium indicative of mucus environment. Following antibiotic treatment, a massive increase in the prevalence of Verrucomicrobia, specifically Akkermansia muciniphila, has been observed. ${ }^{138}$

With chronic idiopathic diarrhea, its prevalence increases together with the increase in the thickness of the mucus layer and the number of fecal mucus striae.

However, it should be noted that in other conditions as obesity, the numbers of Akkermansia decrease below the normal level, indicative of a thinner, weakened mucus, permitting metabolic endotoxins to enter the bloodstream and cause the chronic inflammation associated with obesity. ${ }^{139}$

It is plausible that the prevalence of Akkermansia again gets reduced toward a more normal level upon $S$. boulardii therapy in chronic idiopathic diarrhea, correlated with a reduction of the excessive (but unstable) mucus. ${ }^{18}$

Following antibiotic-induced dysbiosis, Akkermansia, and specifically $A$. muciniphila, gets strongly reduced and only regenerates slowly; this regeneration back to normal levels can be significantly supported by $S$. boulardii ${ }^{118,119}$ and is likely to go along with the regeneration of a stable mucus layer of sufficient thickness.

\section{Other members of the microbiota}

The literature describes an increasing number of minor genera as potential microbiota inhabitants. At the same time, the nonbacterial microbiota like archaea, fungi, eukaryotes, and viruses also have their place within this complex ecosystem. Especially the role of methanogenic archaea within the colon requires more attention. ${ }^{140}$ Altogether, a description of what happens to these other members of the microbiota during different types of dysbiosis and during $S$. boulardii treatment is awaiting future research.

\section{Discussion and conclusion - outlook on the potential of S. boulardii}

One of the challenges in investigating the composition of the intestinal ecosystem is the detection of minor species within a fecal sample - or finding the needle in a haystack of up to $1,000,000,000,000$ bacteria/g. Fortunately, the methodology for a quantitative detection of microbes within a fecal sample has greatly improved in recent years, and will continue to do so. Another challenge is the elucidation of the spatial relationship of different microbial species in health, disease, and therapy.

Previous studies have demonstrated great potential for S. boulardii CNCM I-745 in the recovery from diarrhea or its prevention, eg, regarding a reduction of antibiotic-associated suppression of the microbiota as well as their faster regeneration after antibiotic therapy. Investigations on an increased (initial) dosage as well as an elongated treatment scheme, during and also subsequent to antibiotic treatment, could further improve the protection and recovery from antibioticinduced dysbiosis.

Other dysbiotic conditions too have been shown to profit from S. boulardii, eg, SBS, chronic idiopathic diarrhea, or tube feeding-induced diarrhea.

Owing to its multiple mechanisms of actions, $S$. boulardii is promising also for the treatment of dysbiotic situations, which differ from the classical diarrhea, eg, low-level intestinal inflammatory conditions or even constipation. Furthermore, the application of $S$. boulardii could possibly prevent the spread of many more diarrheic outbreaks, also in the developing world, where diarrhea is still a common cause of death, especially in children.

An additional potential of $S$. boulardii lies in a general stabilization of the gut flora for at-risk populations of the 
industrialized world, namely, the elderly, people with diabetes, overweight people, smokers, or people with high stress levels (Figure 1; risk factors).

More studies are needed to explore the full potential of the versatile probiotic yeast.

\section{Acknowledgments}

We are grateful to Dr Steffi Dudek for reviewing the manuscript.

\section{Author contributions}

All authors contributed toward data analysis, drafting and revising the paper and agree to be accountable for all aspects of the work.

\section{Disclosure}

The work of Dr Margret Moré was funded by Medice Arzneimittel Pütter GmbH and Co. KG. The authors report no other conflicts of interest in this work.

\section{References}

1. Zoetendal EG, Vaughan EE, de Vos WM. A microbial world within us. Mol Microbiol. 2006;59(6):1639-1650.

2. Pituch A, Walkowiak J, Banaszkiewicz A. Butyric acid in functional constipation. Prz Gastroenterol. 2013;8(5):295-298.

3. Kuwahara A. Contributions of colonic short-chain fatty acid receptors in energy homeostasis. Front Endocrinol. 2014;5:144.

4. Royall D, Wolever TM, Jeejeebhoy KN. Clinical significance of colonic fermentation. Am J Gastroenterol. 1990;85(10):1307-1312.

5. Leonel AJ, Alvarez-Leite JI. Butyrate: implications for intestinal function. Curr Opin Clin Nutr Metab Care. 2012;15(5):474-479.

6. Puertollano E, Kolida S, Yaqoob P. Biological significance of shortchain fatty acid metabolism by the intestinal microbiome. Curr Opin Clin Nutr Metab Care. 2014;17(2):139-144.

7. Buckman SA, Heise CP. Nutrition considerations surrounding restorative proctocolectomy. Nutr Clin Pract. 2010;25(3):250-256.

8. Claus SP, Ellero SL, Berger B, et al. Colonization-induced host-gut microbial metabolic interaction. MBio. 2011;2(2):e00271-e00310.

9. Guarner F, Malagelada JR. Gut flora in health and disease. Lancet. 2003;361(9356):512-519.

10. Belkaid Y, Hand TW. Role of the microbiota in immunity and inflammation. Cell. 2014;157(1):121-141.

11. Molloy MJ, Bouladoux N, Belkaid Y. Intestinal microbiota: shaping local and systemic immune responses. Semin Immunol. 2012;24(1): 58-66.

12. Forsythe P, Bienenstock J. Immunomodulation by commensal and probiotic bacteria. Immunol Invest. 2010;39(4-5):429-448.

13. Cani PD. Metabolism in 2013: the gut microbiota manages host metabolism. Nat Rev Endocrinol. 2014;10(2):74-76.

14. Abreu MT. Toll-like receptor signalling in the intestinal epithelium: how bacterial recognition shapes intestinal function. Nat Rev Immunol. 2010;10(2):131-144.

15. Kim YS, Ho SB. Intestinal goblet cells and mucins in health and disease: recent insights and progress. Curr Gastroenterol Rep. 2010; 12(5):319-330.

16. Johansson ME, Phillipson M, Petersson J, Velcich A, Holm L, Hansson GC. The inner of the two Muc2 mucin-dependent mucus layers in colon is devoid of bacteria. Proc Natl Acad Sci USA. 2008;105(39): 15064-15069.
17. Ouwerkerk JP, de Vos WM, Belzer C. Glycobiome: bacteria and mucus at the epithelial interface. Best Pract Res Clin Gastroenterol. 2013; 27(1):25-38.

18. Swidsinski A, Loening-Baucke V, Kirsch S, Doerffel Y. Biostructure fonctionnelle du microbiote colique (zone de fermentation centrale, zone de réserve germinale et couche de mucus séparatrice) chez les sujets sains et chez les patients atteints de diarrhée traités par Saccharomyces boulardii [Functional biostructure of colonic microbiota (central fermenting area, germinal stock area and separating mucus layer) in healthy subjects and patients with diarrhea treated with Saccharomyces boulardii]. Gastroenterol Clin Biol. 2010;34(Suppl 1):S79-S92. French.

19. Swidsinski A, Loening-Baucke V, Herber A. Mucosal flora in Crohn's disease and ulcerative colitis - an overview. J Physiol Pharmacol. 2009;60(Suppl 6):61-71.

20. Strugala V, Dettmar PW, Pearson JP. Thickness and continuity of the adherent colonic mucus barrier in active and quiescent ulcerative colitis and Crohn's disease. Int J Clin Pract. 2008;62(5):762-769.

21. Musso G, Gambino R, Cassader M. Obesity, diabetes, and gut microbiota: the hygiene hypothesis expanded? Diabetes Care. 2010; 33(10):2277-2284.

22. Fernandes J, Su W, Rahat-Rozenbloom S, Wolever TM, Comelli EM. Adiposity, gut microbiota and faecal short chain fatty acids are linked in adult humans. Nutr Diabetes. 2014;4:e121.

23. Stokholm J, Schjorring S, Eskildsen CE, et al. Antibiotic use during pregnancy alters the commensal vaginal microbiota. Clin Microbiol Infect. 2014;20(7):629-635.

24. O'Sullivan O, Coakley M, Lakshminarayanan B, et al. Alterations in intestinal microbiota of elderly Irish subjects post-antibiotic therapy. J Antimicrob Chemother. 2013;68(1):214-221.

25. Grover M. Role of gut pathogens in development of irritable bowel syndrome. Indian J Med Res. 2014;139(1):11-18.

26. Schneider SM, Le Gall P, Girard-Pipau F, et al. Total artificial nutrition is associated with major changes in the fecal flora. Eur J Nutr. 2000; 39(6):248-255.

27. Schneider SM. Nutrition entérale et microbiote [Microbiota and enteral nutrition]. Gastroenterol Clin Biol. 2010;34(Suppl 1):S57-S61. French.

28. O'Keefe SJ, Ou J, Delany JP, et al. Effect of fiber supplementation on the microbiota in critically ill patients. World J Gastrointest Pathophysiol. 2011;2(6):138-145.

29. Nakao M, Ogura Y, Satake S, et al. Usefulness of soluble dietary fiber for the treatment of diarrhea during enteral nutrition in elderly patients. Nutrition. 2002;18(1):35-39.

30. Chey WD, Cash BD. Irritable bowel syndrome: update on colonic neuromuscular dysfunction and treatment. Curr Gastroenterol Rep. 2006;8(4):273-281.

31. Ghoshal UC, Srivastava D. Irritable bowel syndrome and small intestinal bacterial overgrowth: meaningful association or unnecessary hype. World J Gastroenterol. 2014;20(10):2482-2491.

32. Walker AW, Sanderson JD, Churcher C, et al. High-throughput clone library analysis of the mucosa-associated microbiota reveals dysbiosis and differences between inflamed and non-inflamed regions of the intestine in inflammatory bowel disease. BMC Microbiol. 2011;11:7.

33. Thomas LV, Ockhuizen T, Suzuki K. Exploring the influence of the gut microbiota and probiotics on health: a symposium report. Br J Nutr. 2014;112(Suppl 1):S1-S18.

34. Surawicz CM. Le microbiote dans les diarrhées infectieuses [The microbiota and infectious diarrhea]. Gastroenterol Clin Biol. 2010; 34(Suppl 1):S29-S36. French.

35. Kolling G, Wu M, Guerrant RL. Enteric pathogens through life stages. Front Cell Infect Microbiol. 2012;2:114.

36. Ma C, Wu X, Nawaz M, et al. Molecular characterization of fecal microbiota in patients with viral diarrhea. Curr Microbiol. 2011;63(3): 259-266.

37. Thabane M, Kottachchi DT, Marshall JK. Systematic review and metaanalysis: the incidence and prognosis of post-infectious irritable bowel syndrome. Aliment Pharmacol Ther. 2007;26(4):535-544. 
38. Barbara G, Stanghellini V, Berti-Ceroni C, et al. Role of antibiotic therapy on long-term germ excretion in faeces and digestive symptoms after Salmonella infection. Aliment Pharmacol Ther. 2000; 14(9):1127-1131.

39. Voth DE, Ballard JD. Clostridium difficile toxins: mechanism of action and role in disease. Clin Microbiol Rev. 2005;18(2):247-263.

40. Wang L, Conlon MA, Christophersen CT, Sorich MJ, Angley MT. Gastrointestinal microbiota and metabolite biomarkers in children with autism spectrum disorders. Biomark Med. 2014;8(3): 331-344.

41. Kang DW, Park JG, Ilhan ZE, et al. Reduced incidence of Prevotella and other fermenters in intestinal microflora of autistic children. PLoS One. 2013;8(7):e68322.

42. Swidsinski A, Loening-Baucke V, Krüger M, Kirsch S. Central nervous system and the colonic bioreactor: analysis of colonic microbiota in patients with stroke unravels unknown mechanisms of the host defense after brain injury. Intest Res. 2012;10(4):332-342.

43. Kimura I, Ozawa K, Inoue D, et al. The gut microbiota suppresses insulin-mediated fat accumulation via the short-chain fatty acid receptor GPR43. Nat Commun. 2013;4:1829.

44. Moayyedi P. The epidemiology of obesity and gastrointestinal and other diseases: an overview. Dig Dis Sci. 2008;53(9):2293-2299.

45. Kanauchi O, Matsumoto Y, Matsumura M, Fukuoka M, Bamba T. The beneficial effects of microflora, especially obligate anaerobes, and their products on the colonic environment in inflammatory bowel disease. Curr Pharm Des. 2005;11(8):1047-1053.

46. Forster $\mathrm{C}$. Tight junctions and the modulation of barrier function in disease. Histochem Cell Biol. 2008;130(1):55-70.

47. Thanabalasuriar A, Koutsouris A, Weflen A, Mimee M, Hecht G, Gruenheid S. The bacterial virulence factor NleA is required for the disruption of intestinal tight junctions by enteropathogenic Escherichia coli. Cell Microbiol. 2010;12(1):31-41.

48. Shen L. Tight junctions on the move: molecular mechanisms for epithelial barrier regulation. Ann N Y Acad Sci. 2012;1258:9-18.

49. Swidsinski A, Loening-Baucke V, Verstraelen H, Osowska S, Doerffel Y. Biostructure of fecal microbiota in healthy subjects and patients with chronic idiopathic diarrhea. Gastroenterology. 2008;135(2): 568-579.

50. Swidsinski A, Ung V, Sydora BC, et al. Bacterial overgrowth and inflammation of small intestine after carboxymethylcellulose ingestion in genetically susceptible mice. Inflamm Bowel Dis. 2009;15(3): 359-364.

51. Zhu L, Liu W, Alkhouri R, et al. Structural changes in the gut microbiome of constipated patients. Physiol Genomics. 2014;46(18):679-686.

52. Chassard C, Dapoigny M, Scott KP, et al. Functional dysbiosis within the gut microbiota of patients with constipated-irritable bowel syndrome. Aliment Pharmacol Ther. 2012;35(7):828-838.

53. Czerucka D, Piche T, Rampal P. Review article: yeast as probiotics - Saccharomyces boulardii. Aliment Pharmacol Ther. 2007; 26(6):767-778.

54. Liti G, Carter DM, Moses AM, et al. Population genomics of domestic and wild yeasts. Nature. 2009;458(7236):337-341.

55. MacKenzie DA, Defernez M, Dunn WB, et al. Relatedness of medically important strains of Saccharomyces cerevisiae as revealed by phylogenetics and metabolomics. Yeast. 2008;25(7):501-512.

56. Blehaut H, Massot J, Elmer GW, Levy RH. Disposition kinetics of Saccharomyces boulardii in man and rat. Biopharm Drug Dispos. 1989;10(4):353-364.

57. Elmer GW, McFarland LV, Surawicz CM, Danko L, Greenberg RN. Behaviour of Saccharomyces boulardii in recurrent Clostridium difficile disease patients. Aliment Pharmacol Ther. 1999;13(12):1663-1668.

58. Barc MC, Charrin-Sarnel C, Rochet V, et al. Molecular analysis of the digestive microbiota in a gnotobiotic mouse model during antibiotic treatment: influence of Saccharomyces boulardii. Anaerobe. 2008; 14(4):229-233.

59. Munoz P, Bouza E, Cuenca-Estrella M, et al. Saccharomyces cerevisiae fungemia: an emerging infectious disease. Clin Infect Dis. 2005; 40(11):1625-1634
60. Llopis S, Querol A, Heyken A, et al. Transcriptomics in human blood incubation reveals the importance of oxidative stress response in Saccharomyces cerevisiae clinical strains. BMC Genomics. 2012;13:419.

61. Perez-Torrado R, Llopis S, Perrone B, Gomez-Pastor R, Hube B, Querol A. comparative genomic analysis reveals a critical role of de novo nucleotide biosynthesis for Saccharomyces cerevisiae virulence. PLoS One. 2015;10(3):e122382.

62. Edwards-Ingram L, Gitsham P, Burton N, et al. Genotypic and physiological characterization of Saccharomyces boulardii, the probiotic strain of Saccharomyces cerevisiae. Appl Environ Microbiol. 2007; 73(8):2458-2467.

63. Graff S, Chaumeil JC, Boy P, Lai-Kuen R, Charrueau C. Influence of $\mathrm{pH}$ conditions on the viability of Saccharomyces boulardii yeast. J Gen Appl Microbiol. 2008;54(4):221-227.

64. Czerucka D, Nano JL, Bernasconi P, Rampal P. Effect of Saccharomyces boulardii on cholera toxin-induced camp level in rat epithelial intestinal cell lines. Gastroenterol Clin Biol. 1989;13:383-387.

65. Elmer GW, Corthier G. Modulation of Clostridium difficile induced mortality as a function of the dose and the viability of the Saccharomyces boulardii used as a preventative agent in gnotobiotic mice. Can J Microbiol. 1991;37(4):315-317.

66. Schwenzer V. Saccharomyces boulardii. Deutsche Apotheker Zeitung 1998; 138:75-77.

67. Dinleyici EC, Kara A, Ozen M, Vandenplas Y. Saccharomyces boulardii CNCM I-745 in different clinical conditions. Expert Opin Biol Ther. 2014:1-17.

68. McFarland LV. Systematic review and meta-analysis of Saccharomyces boulardii in adult patients. World J Gastroenterol. 2010; 16(18):2202-2222.

69. Zanello G, Meurens F, Berri M, Salmon H. Saccharomyces boulardii effects on gastrointestinal diseases. Curr Issues Mol Biol. 2009; 11(1):47-58

70. McFarland LV. Use of probiotics to correct dysbiosis of normal microbiota following disease or disruptive events: a systematic review. $B M J$ Open. 2014;4(8):e005047.

71. Micklefield G. Saccharomyces coulardii bei Antibiotika-assoziierter Diarrhöe [Saccharomyces boulardii with antibiotic-associated diarrhea]. MMW-Fortschritte der Medizin Originalien 2014;156(1 Suppl):18-22. German

72. Na X, Kelly C. Probiotics in Clostridium difficile infection. J Clin Gastroenterol. 2011;45(Suppl):S154-S158.

73. Tung JM, Dolovich LR, Lee CH. Prevention of Clostridium difficile infection with Saccharomyces boulardii: a systematic review. Can J Gastroenterol. 2009;23(12):817-821.

74. Kollaritsch H, Holst H, Grobara P, Wiedermann G. Prophylaxe der reisediarrhoe mit Saccharomyces boulardii [Prevention of traveler's diarrhea with Saccharomyces boulardii. Results of a placebo controlled double-blind study]. Fortschr Med. 1993;111(9):152-156. German.

75. Feizizadeh S, Salehi-Abargouei A, Akbari V. Efficacy and safety of Saccharomyces boulardii for acute diarrhea. Pediatrics. 2014;134(1): e176-e191.

76. Guandalini S. Probiotics for children with diarrhea: an update. J Clin Gastroenterol. 2008;42(Suppl 2):S53-S57.

77. Whelan K. Enteral-tube-feeding diarrhoea: manipulating the colonic microbiota with probiotics and prebiotics. Proc Nutr Soc. 2007; 66(3):299-306.

78. Tempe JD, Steidel AL, Blehaut H, Hasselmann M, Lutun P, Maurier F. Prévention per Saccharomyces boulardii des diarrhées de l'alimentation entérale à débit continu [Prevention of diarrhea administering Saccharomyces boulardii during continuous enteral feeding]. Sem Hop. 1983;59(18):1409-1412. French.

79. Schlotterer M, Bernasconi P, Lebreton F, et al. Intérêt de Saccharomyces boulardii dans la tolerance digestive de la nutrition entérale à debit continu chez le brulé. [Use of Saccharomyces boulardii for the improvement of the tolerance of continuous enteral feeding in burn patients]. Nutr Clin Metabol. 1987;1:31-34. French. 
80. Bleichner G, Blehaut H, Mentec H, Moyse D. Saccharomyces boulardii prevents diarrhea in critically ill tube-fed patients. A multicenter, randomized, double-blind placebo-controlled trial. Intensive Care Med. 1997;23(5):517-523.

81. Kelesidis T, Pothoulakis C. Efficacy and safety of the probiotic Saccharomyces boulardii for the prevention and therapy of gastrointestinal disorders. Ther Adv Gastroenterol. 2012;5(2):111-125.

82. Barreto-Bergter E, Figueiredo RT. Fungal glycans and the innate immune recognition. Front Cell Infect Microbiol. 2014;4:145.

83. Samuelsen AB, Schrezenmeir J, Knutsen SH. Effects of orally administered yeast-derived $\beta$-glucans: a review. Mol Nutr Food Res. 2014; 58(1):183-193.

84. Vannucci L, Krizan J, Sima P, et al. Immunostimulatory properties and antitumor activities of glucans (Review). Int J Oncol. 2013; 43(2):357-364.

85. Goodridge HS, Reyes CN, Becker CA, et al. Activation of the innate immune receptor Dectin-1 upon formation of a 'phagocytic synapse'. Nature. 2011;472(7344):471-475.

86. Pothoulakis C. Review article: anti-inflammatory mechanisms of action of Saccharomyces boulardii. Aliment Pharmacol Ther. 2009; 30(8):826-833.

87. Mumy KL, Chen X, Kelly CP, McCormick BA. Saccharomyces boulardii interferes with Shigella pathogenesis by postinvasion signaling events. Am J Physiol Gastrointest Liver Physiol. 2008; 294(3):G599-G609.

88. Pontier-Bres R, Munro P, Boyer L, et al. Saccharomyces boulardii modifies Salmonella typhimurium traffic and host immune responses along the intestinal tract. PLoS One. 2014;9(8):e103069.

89. Rajput IR, Li LY, Xin X, et al. Effect of Saccharomyces boulardii and Bacillus subtilis B10 on intestinal ultrastructure modulation and mucosal immunity development mechanism in broiler chickens. Poult Sci. 2013;92(4):956-965.

90. Martins FS, Vieira AT, Elian SD, et al. Inhibition of tissue inflammation and bacterial translocation as one of the protective mechanisms of Saccharomyces boulardii against Salmonella infection in mice. Microbes Infect. 2013;15(4):270-279.

91. Girard P, Pansart Y, Coppe MC, Gillardin JM. Saccharomyces boulardii inhibits water and electrolytes changes induced by castor oil in the rat colon. Dig Dis Sci. 2005;50(11):2183-2190.

92. Schroeder B, Winckler C, Failing K, Breves G. Studies on the time course of the effects of the probiotic yeast Saccharomyces boulardii on electrolyte transport in pig jejunum. Dig Dis Sci. 2004; 49(7-8):1311-1317.

93. Czerucka D, Rampal P. Effect of Saccharomyces boulardii on cAMPand $\mathrm{Ca}^{2+}$-dependent Cl-secretion in T84 cells. Dig Dis Sci. 1999; 44(11):2359-2368.

94. Buccigrossi V, Laudiero G, Russo C, et al. Chloride secretion induced by rotavirus is oxidative stress-dependent and inhibited by Saccharomyces boulardii in human enterocytes. PLoS One. 2014;9(6):e99830.

95. Schneider SM, Girard-Pipau F, Filippi J, et al. Effects of Saccharomyces boulardii on fecal short-chain fatty acids and microflora in patients on long-term total enteral nutrition. World $J$ Gastroenterol. 2005;11(39):6165-6169.

96. Breves G, Faul K, Schroder B, Holst H, Caspary WF, Stein J. Application of the colon-simulation technique for studying the effects of Saccharomyces boulardii on basic parameters of porcine cecal microbial metabolism disturbed by clindamycin. Digestion. 2000; 61(3):193-200.

97. Oeztuerk H, Schroeder B, Beyerbach M, Breves G. Influence of living and autoclaved yeasts of Saccharomyces boulardii on in vitro ruminal microbial metabolism. J Dairy Sci. 2005;88(7):2594-2600.

98. Jahn HU, Ullrich R, Schneider T, et al. Immunological and trophical effects of Saccharomyces boulardii on the small intestine in healthy human volunteers. Digestion. 1996;57(2):95-104.

99. Buts JP, De Keyser N, De Raedemaeker L. Saccharomyces boulardii enhances rat intestinal enzyme expression by endoluminal release of polyamines. Pediatr Res. 1994;36(4):522-527.
100. Buts JP, De Keyser N, Marandi S, et al. Saccharomyces boulardii upgrades cellular adaptation after proximal enterectomy in rats. Gut. 1999;45(1):89-96.

101. Castagliuolo I, LaMont JT, Nikulasson ST, Pothoulakis C. Saccharomyces boulardii protease inhibits Clostridium difficile toxin A effects in the rat ileum. Infect Immun. 1996;64(12):5225-5232.

102. Brandao RL, Castro IM, Bambirra EA, et al. Intracellular signal triggered by cholera toxin in Saccharomyces boulardii and Saccharomyces cerevisiae. Appl Environ Microbiol. 1998;64(2):564-568.

103. Buts JP, Dekeyser N, Stilmant C, Delem E, Smets F, Sokal E. Saccharomyces boulardii produces in rat small intestine a novel protein phosphatase that inhibits Escherichia coli endotoxin by dephosphorylation. Pediatr Res. 2006;60(1):24-29.

104. Tiago FC, Martins FS, Souza EL, et al. Adhesion to the yeast cell surface as a mechanism for trapping pathogenic bacteria by Saccharomyces probiotics. J Med Microbiol. 2012;61(Pt 9):1194-1207.

105. Martins FS, Dalmasso G, Arantes RM, et al. Interaction of Saccharomyces boulardii with Salmonella enterica serovar Typhimurium protects mice and modifies T84 cell response to the infection. PLoS One. 2010;5(1):e8925.

106. Gedek BR. Adherence of Escherichia coli serogroup O 157 and the Salmonella typhimurium mutant DT 104 to the surface of Saccharomyces boulardii. Mycoses. 1999;42(4):261-264.

107. Zbinden R, Gönczi E-E, Altwegg M. Inhibition of Saccharomyces boulardii (nom. inval.) on cell invasion of Salmonella typhimurium and Yersinia enterocolitica. Microb Ecol Health Dis. 2011;11(3). ISSN 1651-2235.

108. Ducluzeau R, Bensaada M. [Comparative effect of a single or continuous administration of "Saccharomyces boulardii" on the establishment of various strains of "candida" in the digestive tract of gnotobiotic mice]. Ann Microbiol. 1982;133(3):491-501. French.

109. Kamada N, Chen GY, Inohara N, Nunez G. Control of pathogens and pathobionts by the gut microbiota. Nat Immunol. 2013;14(7): 685-690.

110. Geurts L, Lazarevic V, Derrien M, et al. Altered gut microbiota and endocannabinoid system tone in obese and diabetic leptin-resistant mice: impact on apelin regulation in adipose tissue. Front Microbiol. 2011;2:149.

111. Everard A, Matamoros S, Geurts L, Delzenne NM, Cani PD. Saccharomyces boulardii administration changes gut microbiota and reduces hepatic steatosis, low-grade inflammation, and fat mass in obese and type 2 diabetic db/db mice. MBio. 2014;5(3):e01011-e01014.

112. Akil I, Yilmaz O, Kurutepe S, Degerli K, Kavukcu S. Influence of oral intake of Saccharomyces boulardii on Escherichia coli in enteric flora. Pediatr Nephrol. 2006;21(6):807-810.

113. De Preter V, Vanhoutte T, Huys G, Swings J, Rutgeerts P, Verbeke K. Effect of lactulose and Saccharomyces boulardii administration on the colonic urea-nitrogen metabolism and the bifidobacteria concentration in healthy human subjects. Aliment Pharmacol Ther. 2006; 23(7):963-974.

114. Girard-Pipau F, Pompei A, Schneider S, et al. Intestinal microflora, short chain and cellular fatty acids, influence of a probiotic Saccharomyces boulardii. Microb Ecolo Health Dis. 2002;14:220-227.

115. Vanhoutte T, De Preter V, De Brandt E, Verbeke K, Swings J, Huys G. Molecular monitoring of the fecal microbiota of healthy human subjects during administration of lactulose and Saccharomyces boulardii. Appl Environ Microbiol. 2006;72(9):5990-5997.

116. Kelly C. Antibiotic-induced dysbiosis and corrective impact of $S$. boulardii in healthy volunteers (Abstract-JFHOD conference). United Eur Gastroenterol J. 2014;2(Suppl 1).

117. Osowska S, Swidsinski A, Kulik Z, Lawinski M, Pertkiewicz M. Impact of saccharomyces boulardii on colonic microbiota and plasma lactate in short bowel syndrome patients on long term parenteral nutrition. Dig Dis Week. 2013;144(5):s895.

118. Swidsinski A. Antibiotic-induced dysbiosis and corrective impact of $S$. boulardii - evaluation by structure functional FISH analysis in patients with a Gardnerella vaginalis infection. Abstract-JFHOD conference. 2014. 
119. Swidsinski A, Loening-Baucke V, Swidsinski S. Saccharomyces boulardii prevents the antibiotic induced changes in colonic microbiota. Gastroenterology. 2013;144(5 Suppl 1):S-824.

120. Staib L, Fuchs TM. From food to cell: nutrient exploitation strategies of enteropathogens. Microbiology. 2014;160(Pt 6):1020-1039.

121. Chen SJ, Liu XW, Liu JP, Yang XY, Lu FG. Ulcerative colitis as a polymicrobial infection characterized by sustained broken mucus barrier. World J Gastroenterol. 2014;20(28):9468-9475.

122. Wexler HM. Bacteroides: the good, the bad, and the nitty-gritty. Clin Microbiol Rev. 2007;20(4):593-621.

123. Zitomersky NL, Atkinson BJ, Franklin SW, et al. Characterization of adherent bacteroidales from intestinal biopsies of children and young adults with inflammatory bowel disease. PLoS One. 2013; 8(6):e63686.

124. Manz W, Amann R, Ludwig W, Vancanneyt M, Schleifer KH. Application of a suite of $16 \mathrm{~S}$ rRNA-specific oligonucleotide probes designed to investigate bacteria of the phylum cytophaga-flavobacter-bacteroides in the natural environment. Microbiology. 1996;142(Pt 5):1097-1106.

125. Yutin N, Galperin MY. A genomic update on clostridial phylogeny: Gram-negative spore formers and other misplaced clostridia. Environ Microbiol. 2013;15(10):2631-2641.

126. Vital M, Howe AC, Tiedje JM. Revealing the bacterial butyrate synthesis pathways by analyzing (meta)genomic data. MBio. 2014;5(2):e00889.

127. NCBI Taxomomy Browser. Taxomomy Browser. Available from: http:// www.ncbi.nlm.nih.gov/Taxonomy/Browser/wwwtax.cgi. Accessed July 2, 2015.

128. Kabeerdoss J, Sankaran V, Pugazhendhi S, Ramakrishna BS. Clostridium leptum group bacteria abundance and diversity in the fecal microbiota of patients with inflammatory bowel disease: a case-control study in India. BMC Gastroenterol. 2013;13:20.

129. Sokol H, Pigneur B, Watterlot L, et al. Faecalibacterium prausnitzii is an anti-inflammatory commensal bacterium identified by gut microbiota analysis of Crohn disease patients. Proc Natl Acad Sci U S A 2008;105(43):16731-16736.

130. Qiu X, Zhang M, Yang X, Hong N, Yu C. Faecalibacterium prausnitzii upregulates regulatory $\mathrm{T}$ cells and anti-inflammatory cytokines in treating TNBS-induced colitis. J Crohns Colitis. 2013;7(11):e558-e568.

131. Kumari A, Catanzaro R, Marotta F. Clinical importance of lactic acid bacteria: a short review. Acta Biomed. 2011;82(3):177-180.

132. Turpin W, Humblot C, Thomas M, Guyot JP. Lactobacilli as multifaceted probiotics with poorly disclosed molecular mechanisms. Int J Food Microbiol. 2010;143(3):87-102.

133. Iqbal MZ, Qadir MI, Hussain T, Janbaz KH, Khan YH, Ahmad B. Review: probiotics and their beneficial effects against various diseases. Pak J Pharm Sci. 2014;27(2):405-415.

134. Lay C, Rigottier-Gois L, Holmstrom K, et al. Colonic microbiota signatures across five northern European countries. Appl Environ Microbiol. 2005;71(7):4153-4155.
135. Thiennimitr $\mathrm{P}$, Winter SE, Winter MG, et al. Intestinal inflammation allows Salmonella to use ethanolamine to compete with the microbiota. Proc Natl Acad Sci U S A. 2011;108(42):17480-17485.

136. Philippe-Taine G, Coroler L, Levy R, Gillardin J. Dose-dependent preventive effect of Saccharomyces boulardii on clindamycin-induced alterations in intestinal aerobic flora of the hamster. Microbial Ecol Health Dis. 2003;15:126-130.

137. Collignon A, Sandre C, Barc MC. Saccharomyces boulardii module les propriétés des cellules dendritiques et le déséquilibre du microbiote intestinal après un traitement antibiotique [Saccharomyces boulardii modulates dendritic cell properties and intestinal microbiota disruption after antibiotic treatment]. Gastroenterol Clin Biol. 2010;34(Suppl 1) S71-S78. French.

138. Dubourg G, Lagier JC, Armougom F, et al. High-level colonisation of the human gut by Verrucomicrobia following broad-spectrum antibiotic treatment. Int J Antimicrob Agents. 2013;41(2):149-155.

139. Bradlow HL. Obesity and the gut microbiome: pathophysiological aspects. Hormone Mol Biol Clin Invest. 2014;17(1):53-61.

140. Scanlan PD, Shanahan F, Marchesi JR. Human methanogen diversity and incidence in healthy and diseased colonic groups using morA gene analysis. BMC Microbiol. 2008;8:79.

141. Loy A, Maixner F, Wagner M, Horn M. probeBase - an online resource for rRNA-targeted oligonucleotide probes: new features 2007. Nucleic Acids Res. 2007;35(Database issue):D800-D804.

142. Turnbaugh PJ, Ley RE, Mahowald MA, Magrini V, Mardis ER, Gordon JI. An obesity-associated gut microbiome with increased capacity for energy harvest. Nature. 2006;444(7122):1027-1031.

143. Sghir A, Gramet G, Suau A, Rochet V, Pochart P, Dore J. Quantification of bacterial groups within human fecal flora by oligonucleotide probe hybridization. Appl Environ Microbiol. 2000;66(5):2263-2266.

144. Matsuki T, Watanabe K, Fujimoto J, Takada T, Tanaka R. Use of $16 \mathrm{~S}$ rRNA gene-targeted group-specific primers for real-time PCR analysis of predominant bacteria in human feces. Appl Environ Microbiol. 2004;70(12):7220-7228

145. Franks AH, Harmsen HJ, Raangs GC, Jansen GJ, Schut F, Welling GW. Variations of bacterial populations in human feces measured by fluorescent in situ hybridization with group-specific 16S rRNAtargeted oligonucleotide probes. Appl Environ Microbiol. 1998;64(9): 3336-3345.

146. Harmsen HJ, Wildeboer-Veloo AC, Grijpstra J, Knol J, Degener JE, Welling GW. Development of $16 \mathrm{~S}$ rRNA-based probes for the Coriobacterium group and the Atopobium cluster and their application for enumeration of Coriobacteriaceae in human feces from volunteers of different age groups. Appl Environ Microbiol. 2000; 66(10):4523-4527.
Clinical and Experimental Gastroenterology

\section{Publish your work in this journal}

Clinical and Experimental Gastroenterology is an international, peerreviewed, open access journal, publishing all aspects of gastroenterology in the clinic and laboratory, including: Pathology, pathophysiology of gastrointestinal disease; Investigation and treatment of gastointestinal disease; Pharmacology of drugs used in the alimentary tract;

\section{Dovepress}

Immunology/genetics/genomics related to gastrointestinal disease. This journal is indexed on CAS. The manuscript management system is completely online and includes a very quick and fair peer-review system. Visit http://www.dovepress.com/testimonials.php to read real quotes from published authors. 